\title{
The provenance of serpentinite tools in the Corded Ware culture of Moravia (Czech Republic)
}

\author{
Pavlína FRÝBOVÁ ${ }^{1, *}$, Petr GADAS ${ }^{1}$, Antonín PŘICHYSTAL $^{1}$, Dalibor VŠIANSKÝ ${ }^{1}$ \\ Roman HADACZ ${ }^{2}$ and Petr HLAVSA ${ }^{3}$ \\ 1 Masaryk University, Department of Geological Sciences, Kotlářská 2, 61137 Brno, Czech Republic \\ 2 Garmur.cz, s.r.o., Nebovidy 497, 66448 Brno, Czech Republic \\ 3 Brno University of Technology, Faculty of Architecture, Poříčí 5, 63900 Brno, Czech Republic
}

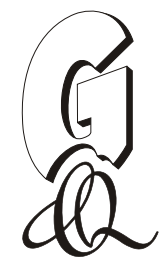

Frýbová, P., Gadas, P., Přichystal, A., Všianský, D., Hadacz, R., Hlavsa, P., 2018. The provenance of serpentinite tools in the Corded Ware culture of Moravia (Czech Republic). Geological Quarterly, 62 (3): 563-578, doi: 10.7306/gq.1437

\begin{abstract}
This paper constrains the provenance of polished tools used in the Corded Ware culture (CWC) in Moravia. Based on optical microscopy, Prichystal and Šebela (1992) suggested the source for the CWC battle-axes would be the Gogołów-Jordanów Massif in Lower Silesia (Poland). The present study examines 14 serpentinite tools from archaeological sites of Central Moravia. We have located the origin of the tools' raw material by applying detailed petrographic, geochemical and petrophysical methods, as well as comparisons with data from probable serpentinite sources. Possible sources are adjacent to the Sowie Góry Block (mainly the Gogołów-Jordanów Massif) and within other areas in Central Europe (Penninic Bernstein Window, Western Lugicum and the eastern part of the Moldanubicum). Its most probable source is the Gogołów-Jordanów Massif, which is a part of the Ślę a ophiolite. The tools resemble the raw material source in several ways: firstly in magnetic susceptibility, with an average value of $\sim 40 \times 10-3 \mathrm{SI}$; secondly, in the light yellowish-green patched patinated surface and very strong serpentinisation with almost no primary mineral relics; and lastly, in the occurrence of pseudomorphs filled with opaque minerals, and also parts with magnesite aggregates, which are quite rare. The main common feature is the presence of large primary zoned spinels, with $\mathrm{Cr}$ - and Al-rich cores and Fe-rich rims. The conclusions are supported by the results of bulk-rock chemical analysis, both the raw material from Lower Silesia and the tools being Mg-rich. In addition, the shape of some Moravian battle-axes (from Prusinovice) corresponds to the Śle a type that is believed to be characteristic of Lower Silesia. The estimated distance of transport from the source area in Gogołów-Jordanów Massif to the archaeological sites in Central Moravia is $>260 \mathrm{~km}$.
\end{abstract}

Key words: battle-axes, Corded Ware culture, Moravia, serpentinite tools, Gogołów-Jordanów Massif, petroarchaeology.

\section{INTRODUCTION}

Serpentinite began to appear as a rare raw material of polished stone tools from the beginning of the Neolithic period (Prichystal, 1984). In the Early Eneolithic period, perforated axe hammers started to predominate. This prevalence caused a change of raw materials, from the prevailing foliated metabasites to rocks with massive structure. Therefore, igneous, sedimentary and metamorphic rocks, primarily serpentinites and olivine basalts, became of interest (Prichystal, 2000).

Serpentinite is a rock with a massive structure consisting mostly of serpentine group minerals, which form flat, cylindrical and corrugated microstructures, reflecting the energetically efficient layering of alternate tetrahedral and octahedral sheets (Guillot and Hattori, 2013). The rock was used for its relative

* Corresponding author, e-mail: pavazn@seznam.cz Received: June 15, 2017; accepted: May 26, 2018; first published online: 8 November, 2018. softness and the high lustre of its polished surface, with an attractive olive-green colour and a smooth but scaly appearance. Their name originates from the similarity of the serpentinite texture to the skin of a snake (the Latin Serpentes, meaning "serpents"). Since antiquity, it has been used worldwide to make jewelry and ceremonial and ornamental carvings (Evans et al., 2013).

Between 2900-2350 BC the Corded Ware culture (CWC) was spread over a vast area of northern, central and eastern Europe. Its characteristic feature is pottery with the print of a twisted cord and stone battle-axes (Mallory and Adams, 1997). Serpentinites played a key role in this culture. Important data concerning raw materials of the CWC battle-axes appeared before the Second World War. In the first half of the 1980s, practically the entire accessible polished stone industry connected with the CWC from Moravia and the adjacent part of Silesia was investigated (Přichystal and Šebela, 1992).

This paper examines the assumption that the serpentinites of Lower Silesia were the raw materials for the polished stone tools used in the Eneolithic period in Moravia and Czech Silesia (Príichystal and Šebela, 1992). To determine provenance, the authors used macroscopical and typological similarities and, primarily, the study of thin-sections under a polarising micro- 
scope. A very good conformity was found between the battle-axes' raw material and serpentinite of the prehistoric mines described by Wojciechowski (1983) from the Gogołów-Jordanów Massif. This similarity is supported by the occurrence of the Ślę a type battle-axes (Fig. 1) which are typical of the probable provenance area.

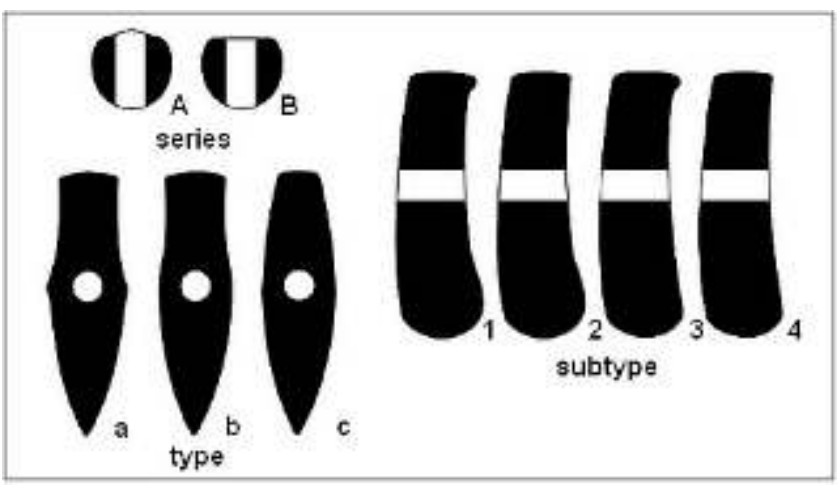

Fig. 1. Proposed classification scheme of Silesian battle-axes of the Ślę a type from the CWC with the division into series, types and subtypes (Chmielewski and Romanow, 2015)

\section{OVERVIEW OF THE SERPENTINITE POTENTIAL SOURCES}

In central Europe, there are many serpentinite occurrences that could provide raw material for polished stone tool production, and thus potential sources have to be selected based on various indicators. One of the main indicators is the direction of intercultural contacts of that time. The distribution routes of raw materials often ran over large distances. Petroarchaeological studies of recent years have shown the presence of workshops near the raw material sources and concentrations of semi-finished polished tools in their vicinity. We can probably exclude serpentinite massifs of the West-Moravian Moldanubicum and Moravian Lugicum from consideration (Přichystal and Šebela, 1992; Přichystal, 2001) as there is no evidence of prehistoric serpentinite mining or larger utilisation of the raw material from these regions. In the serpentinites from the West-Moravian Moldanubicum and Lugicum there are preserved remains of primary minerals which were only slightly altered, and secondary amphibole rarely appears. Pyrope was found in Bohemian serpentinites (in the regions of Kutná Hora and the Svratka crystalline units, Křemže and its surroundings in the South-Bohemian Moldanubicum). The small occurrences in the metabasite zone of the Brno Batholith are also petrographically not comparable to the raw material of the tools analysed (Prichystal, 2000). Serpentinites from the Moldanubicum, Lugicum and the Brno Batholith differ from the raw material of the CWC battle-axes in the presence of olivine, pyroxene or amphibole relics (Prichystal and Šebela, 1992). However, the important serpentinite massifs in the West-Moravian Moldanubicum cannot be completely excluded due to their location relatively near the archaeological sites. Therefore, the most important West-Moravian serpentinite massifs were included in the comparison.

Lower Silesia in Poland. Significant outcrops of serpentinites are situated around the Sowie Góry Block in the Polish part of the Lugicum in the Central Sudetes, Lower Silesia: the Gogołów-Jordanów Massif near Mount Ślę a, the Bra-
szowice-Brzeźnica Massif and the Szklary Massif. These massifs are considered to be fragments of the Central-Sudetic ophiolite (Dubińska and Gunia, 1997; Kryza and Pin, 2010; Wojtulek et al., 2016), and are not overlain by Quaternary deposits.

The Gogołów-Jordanów Massif is an arc-shaped body that surrounds the southern edge of Mount Ślę a, which is the largest of the three serpentinite massifs in Lower Silesia. The massif consists mainly of completely serpentinized ultramafic rocks, originally peridotites (harzburgites, Iherzolites and dunites). Only rarely are fresh or slightly altered ultramafic rocks present. The serpentinites were formed by hydrothermal metamorphism of ultrabasic igneus rocks (peridotite) and are considered to represent tectonically emplaced mantle (Majerowicz and Pin, 1994; Dubińska and Gunia, 1997). A mesh-like microstructure prevails in the serpentinites in the northern part of the massif while a flame-like microstructure with abundant relics of olivine and pyroxene is common in the western and central part of the massif (Majerowicz and Pin, 1989).

The Braszowice-Brzeźnica Massif is situated in the southern part of the Niemcza Dislocation Zone stretching along the fault at the southern margin of the Góry Sowie Block and forming the prominent hills of Grochowiec, named Mnich and Stróžnik. The massif is bordered by the Sudetic Marginal Fault in the south-west and by granitoids and schists of the Niemcza Dislocation Zone in the east. It consists of an ultrabasic unit composed of serpentinized peridotites and mafic units with diallage gabbro and amphibolites (Gunia, 1988). In the serpentinites, a mesh-like microstructure was observed, which occurs particularly in the eastern part of the massif (Gunia, 1992).

The Szklary Massif occupies the southern part of the Niemcza Dislocation Zone, which is considered to be a transverse, left-side shear zone in the northeastern part of the Bohemian Massif. The Szklary Massif is elongated $\mathrm{N}-\mathrm{S}$ and is clearly seen in the landscape as a range of $\mathrm{N}-\mathrm{S}$ aligned hills: Siodłowe, Tomickie and Koźmickie. It stretches out along the eastern flank of the Góry Sowie Block (Mazur and Puziewicz, 1995). The Szklary Massif is composed mainly of serpentinized peridotite, in places with a surface weathered layer with secondary minerals. The primary rocks were probably residual harzburgites (Gunia, 1995, 2000). In the serpentinites, mainly mesh-like and mesh-oriented microstructures occur; the matrix contains relics of olivine with a distinct relief, often penetrated by tiny veins of minerals of the serpentine group - lizardite and chrysotile, which are oriented parallel with square areas filled with relics of olivine (Gunia, 1993).

Use and prehistoric mining of the raw materials from Polish Lower Silesia. The Gogołów-Jordanów Massif is often considered to be a possible source of the serpentinite battle-axes of the CWC in Moravia and Czech Silesia (Prichystal and Šebela, 1992). The raw material was supposedly transported along a prehistoric trade route from Lower Silesia along the Odra River through Upper Silesia towards the Moravian Gate and later to Moravia. This assumption is supported by the typological connection of the material to the so-called Slę a type (Fig. 1) of battle-axe, whose provenance is assumed to have been in the region of Mount Ślę a (Chmielewski and Romanow, 2015). There is also evidence for serpentinite mining from the Gogołów-Jordanów Massif at Jańska Góra by the people of the Funnel Beaker culture. The raw material was used at the site at Janówek and Tomice during the late phase of the culture (dated from $\sim 4400$ to $2600 \mathrm{BC}$; Baldia et al., 2008), only $\sim 1.6 \mathrm{~km}$ from the source (Wojciechowski, 1983). These sites were found to contain a large quantity of semi-finished artefacts and a large volume of waste, including conical products after 
shafthole perforation. The use of this raw material is also assumed for the CWC period (Wojciechowski, 1988). Majerowicz et al. (2000) reported, based on a petrographic study of archaeological collections from Polish Lower Silesia, that 84 serpentinite tools originated from the Gogołów-Jordanów Massif, three from the Braszowice-Brzeźnica source and one from the Szklary Massif, among the sum of 117 artefacts studied. The occurrence of serpentinites from the Gogołów-Jordanów Massif in Lower Silesia towards Upper Silesia and the western part of central Poland was described by Skoczylas et al. (2000), who investigated the usage of the serpentinite by the CWC, as well as by the Funnel Beaker culture and Danubian Neolithic cultures.

No evidence has been found of prehistoric mining in other serpentinite massifs on the southern edge of the Sowie Góry Block and east of it (the Braszowice-Brzeźnica and Szklary Massifs). The artefacts from Lower Silesia show microstructures comparable with serpentinites adjacent to the northern and southern part of the Sowie Gory Block and from the Gogołów-Jordanów Massif especially (Majerowicz et al., 2000). The Gogołów-Jordanów and Braszowice-Brzeźnica Massifs represent easily accessible resources and they often yield a high quality raw material for the manufacture of perforated tools (having massive structure). The Szklary Massif is composed mainly of weathered, disrupted rock, which is not suitable for the manufacture of perforated tools.

Jizera Mountains Piedmont (western Lugicum). Ultrabasic rocks occur in the vicinity of Železný Brod in the Jizera Mountains Piedmont that form a part of western Lugicum. The Železný Brod crystalline complex is situated in the SW margin of the Krkonoše-Jizera crystalline unit and consists mostly of volcano-sedimentary formations, metamorphosed to greenschist, phyllite, quartzite phyllite with inserts of marble and chlorite phyllite. Serpentinized ultrabasic rocks occur as elongated bodies in rocks of the crystalline complex. The ultrabasites have been described under various names; currently, they are interpreted as komatiites and meimechites. Using the IUGS classification, the afore mentioned rocks are in agreement with all parameters of "high-Mg" volcanic rocks and their low $\mathrm{TiO}_{2}$ content ( 1\%) puts them on the komatiite-meimechite boundary (Fediuk, 2006).

These serpentinized ultrabasic rocks occur near the large mining field of metabasites which extended across Central Europe in the Neolithic period (Přichystal, 2002; Šrein et al., 2002).

Bernstein (Penninic Bernstein Window, Eastern Alps). Serpentinites occur in the Penninic Bernstein Window, which is located in the central part of the Burgenland. The polymetamorphic rocks belong to the Bündnerschiefer series and consist of Mesozoic ophiolite remnants, as well as various metasedimentary rocks (Koller, 1985; Dunkl and Demény, 1997). The schists are mainly calc-schists associated with metadiabases and serpentinites (Trümpy, 1988). The serpentinites of Bernstein show different levels of serpentinisation, ranging from partly serpentinized peridotites to fully serpentinized rocks. Some of them are lizarditic serpentinites with pseudomorphic microstructures and some are antigoritic serpentinites with interlocking microstructure (Bernardini et al., 2010).

Serpentinites from the Bernstein area were probably used in the Neolithic and Eneolithic periods (Prichystal, 2013). Hungarian authors (Biró and Szakmány, 2000; Szakmány et al., 2001) consider these serpentinites to be the raw material source of polished tools in the adjacent part of Hungary. Local using of serpentinites in the Neolithic/Eneolithic periods of Austria has been described also from Upper Austria Grömer (2002), southern part of the Moldanubicum from the geological point of view.
Western Moravia - the Moravian Moldanubicum. Serpentinites occur as moderately common isolated bodies within the Gföhl Unit. In the vicinity of Jevišovice there are serpentinites containing abundant siliceous material (opal, chalcedony, green variety of chalcedony called plasma) concentrated at the surface and indicating very strong weathering of surface outcrops. The Jihlava River cuts through two larger serpentinite bodies at Mohelno and Hrubšice. These two large tectonically affected serpentinite-massifs occur in the Náměšt'Moravský Krumlov granulite (Němec, 1937; Hejtman, 1962; Bernard et al., 1981).

The eastern part of the Mohelno Massif is characterized by alternations of serpentinized garnet peridotites and granulites. By contrast, the non-garnet type is typical of the western part (Bernard et al., 1981). According to Němec (1937), the massif contains also several different types of primary rocks (dunite, Iherzolite, amphibole-peridotite, olivine-gabbro).

The eastern margin of the Hrubšice Massif with the Boskovice Furrow was tectonized. According to Hejtman (1962) the Hrubšice Massif is composed of non-garnet serpentinite with magnesite. The Hrubšice serpentinite shows a well-preserved weathering crust, unlike the Mohelno Massif. Magnesite, sepiolite, opal, chalcedony and its green variety (plasma) are known as the weathering products. The occurrence of opals is conditional on the contact of serpentinite and granulite. The plasma can be found south of the Jihlava River west of Hrubšice and in the vicinity of Biskoupky and Nová Ves (Mrázek and Rejl, 1991).

In the Neolithic period, the chipped stone industry is known for the colourful siliceous weathered products of serpentinites from the vicinity of Jevišovice (Přichystal, 1984). It cannot be excluded that fresh serpentinite rocks were known to the people in the Neolithic period and this could occasionally have been used as the raw material for polished tools. Mining of magnesite and sepiolite is known from the Hrubšice Massif on the bank of the Jihlava River from the late 19th century. There is an active quarry named "U Pustého Mlýna" on the right bank of the Jihlava River where the serpentinite has been recently quarried for crushed stone (Mrázek and Rejl, 1991).

\section{MATERIAL AND METHODS}

The serpentinite tools and samples of raw materials from potential sources have been examined macroscopically, and by stereo-microscope and polarizing microscope, kappameter, electron-microprobe and destructive ICP and non-destructive ED-XRF spectrometry.

Fourteen serpentinite tools from various Moravian sites were analysed (Table 1). Four thin-sections from the battle-axes found at the Ježkovice, Brno-Starý Lískovec, Prostějov, and Zdětín sites were prepared. All of the samples relate to the CWC period. The tools were classified based on their macroscopic features into two groups (Group 1 and Group 2). Twenty-eight serpentinite samples from various potential sources (Table 2) were examined to compare them with the material of the battle-axes. A map of the archaeological localities and raw material sources is shown in Figure 2.

The chemical and petrological data was supported by non-destructive techniques used by archaeologists routinely (ED-XRF spectrometry and magnetic susceptibility measurements). Mineral abbreviations in tables, figures and in the text were taken from Whitney and Evans (2010).

Four polished thin-sections from the battle-axes and 26 polished thin+sections from the potential sources were examined 
Overview of the serpentinite tools studied and analytical methods used

\begin{tabular}{|c|c|c|c|c|c|}
\hline Archaeological site & Sample no. & Analytical methods & Group & Inventory no. & Deposition \\
\hline Zdětín & 256 & EMPA, XRD, XRF, MS & 1 & 006086 (Dp15) & \multirow{3}{*}{$\begin{array}{c}\text { Museum and Gallery } \\
\text { Prostějov }\end{array}$} \\
\hline Syrovice & 257 & $\mathrm{XRD}, \mathrm{XRF}, \mathrm{MS}$ & 1 & 006083 (Dp12) & \\
\hline Prostějov & 258 & EMPA, XRD, XRF, MS & 1 & 006598 & \\
\hline Brno-Starý Lískovec & 259 & EMPA, MS & 2 & 303992 & Brno City Museum \\
\hline Ježkovice & 260 & EMPA & 1 & A2930 & Museum Vyškov \\
\hline \multirow{3}{*}{ Prusinovice } & 47 & XRF, MS & 1 & Without inv. no. & \multirow{9}{*}{ Moravian Museum } \\
\hline & 48 & XRF, MS & 1 & Without inv. no. & \\
\hline & 178 & XRF, MS & 1 & 51893 & \\
\hline Dřevohostice & 23 & XRF, MS & 1 & 92883 & \\
\hline Velešovice & 157 & XRF, MS & 2 & 17789/1-60/85 & \\
\hline Blazice & 63 & XRF, MS & 1 & 51844 & \\
\hline Boškůvky & 65 & XRF, MS & 2 & 51827 & \\
\hline Kostelec near Holešov & 77 & XRF, MS & 1 & 131 & \\
\hline Zlobice & 105 & XRF, MS & 1 & 52368 & \\
\hline
\end{tabular}

Table 2

\section{Overview of the serpentinite samples studied from the potential source localities and of the analytical methods used}

\begin{tabular}{|c|c|c|c|c|}
\hline Area & Locality & Geological Setting & Sample no. & Analytical methods \\
\hline \multirow{15}{*}{ Lower Silesia } & \multirow{3}{*}{ Tapadła } & \multirow{10}{*}{$\begin{array}{l}\text { Gogołów-Jordanów } \\
\text { Massif }\end{array}$} & Tąpadła 1 & EMPA ICP, XRD, XRF, MS \\
\hline & & & Tąpadła 2 & EMPA, ICP, XRD, XRF, MS \\
\hline & & & Tąpadła 3 & EMPA, ICP, XRF, MS \\
\hline & \multirow{2}{*}{ Jańska Góra } & & Jańska Góra 1 & EMPA, ICP, XRF, MS \\
\hline & & & Jańska Góra 2 & EMPA, XRF, MS \\
\hline & \multirow{2}{*}{ Wiry } & & Wiry 1 & EMPA, XRF, MS \\
\hline & & & Wiry 2 & EMPA, ICP, XRD, XRF, MS \\
\hline & Gogołów & & Gogołów & EMPA, ICP, XRD, XRF, MS \\
\hline & Jordanów & & Jordanów & EMPA, XRD, XRF, MS \\
\hline & Sobótka & & Sobótka & EMPA, XRF, MS \\
\hline & Braszowice & \multirow{3}{*}{$\begin{array}{c}\text { Braszowice-Brzeźnica } \\
\text { Massif }\end{array}$} & Braszowice & EMPA, ICP, XRD, XRF, MS \\
\hline & \multirow{2}{*}{ Brzeźnica } & & Brzeźnica 1 & EMPA, ICP, XRD, XRF, MS \\
\hline & & & Brzeźnica 2 & EMPA, MS \\
\hline & \multirow{2}{*}{ Szklary } & \multirow{2}{*}{ Szklary Massif } & Szklary 1 & EMPA, ICP, XRF, MS \\
\hline & & & Szklary 2 & EMPA, XRD, XRF, MS \\
\hline \multirow{4}{*}{ Central Burgenland } & \multirow{4}{*}{ Bernstein } & \multirow{4}{*}{$\begin{array}{l}\text { Penninic Bernstein } \\
\text { Window }\end{array}$} & Bernstein 1 & EMPA, ICP, XRF, MS \\
\hline & & & Bernstein 2 & EMPA, ICP, XRD, XRF, MS \\
\hline & & & Rumpersdorf & EMPA, XRD, XRF, MS \\
\hline & & & Bienenhütte & EMPA, XRD, XRF, MS \\
\hline \multirow{4}{*}{$\begin{array}{l}\text { Jizera Mountains } \\
\text { Piedmont }\end{array}$} & \multirow{4}{*}{$\begin{array}{l}\text { The vicinity } \\
\text { of Zelezný Brod }\end{array}$} & \multirow{4}{*}{ Western Lugicum } & Loužnice & EMPA, ICP, XRD, XRF, MS \\
\hline & & & Loužnice-Radčice & EMPA, XRF, MS \\
\hline & & & Klíčnov & EMPA, XRF, MS \\
\hline & & & Alšovice & EMPA, XRF, MS \\
\hline \multirow{5}{*}{ Western Moravia } & \multirow[b]{2}{*}{ Hrubšice Massif } & \multirow{5}{*}{$\begin{array}{l}\text { Moravian } \\
\text { Moldanubicum }\end{array}$} & Hrubšice & EMPA, XRF, MS \\
\hline & & & Biskoupky & $\begin{array}{l}\text { ICP from literature } \\
\text { (Kudělásek, 1965), MS }\end{array}$ \\
\hline & Mohelno Massif & & Mohelno & $\begin{array}{l}\text { ICP from literature (Kudělásek, 1965; } \\
\text { Kudělásková, 1972), MS }\end{array}$ \\
\hline & \multirow{2}{*}{$\begin{array}{l}\text { Gföhl Unit - } \\
\text { Jevišovice district }\end{array}$} & & Černín & EMPA, ICP, MS \\
\hline & & & Bojanovice & EMPA, MS \\
\hline
\end{tabular}

using a Cameca SX-100 electron microprobe at the Joint Laboratory of Electron Microscopy and Analysis of the Department of Geological Sciences at the Faculty of Science, Masaryk University and the Czech Geological Survey. The conditions of the WDX measurements were: accelerating voltage of $15 \mathrm{kV}$, beam current of 10-20 nA and beam diameter 1-5 m. Natural minerals and synthetic phases were used as standards. The raw data were reduced using PAP matrix corrections (Pouchou and Pichoir, 1985). The crystal-chemical formulae of spinels were calculated and normalized to 3 cations and 4 oxygen atoms whereby $\mathrm{Fe}$ was split to $\mathrm{Fe}^{3+}$ or $\mathrm{Fe}^{2+}$ based on stoichiometry. The crystal-chemical formulae of amphiboles were obtained based on 24 anions, where $\left(\mathrm{O}^{2-}+\mathrm{OH}^{-}+\mathrm{F}^{-}\right)=2$, assum- 


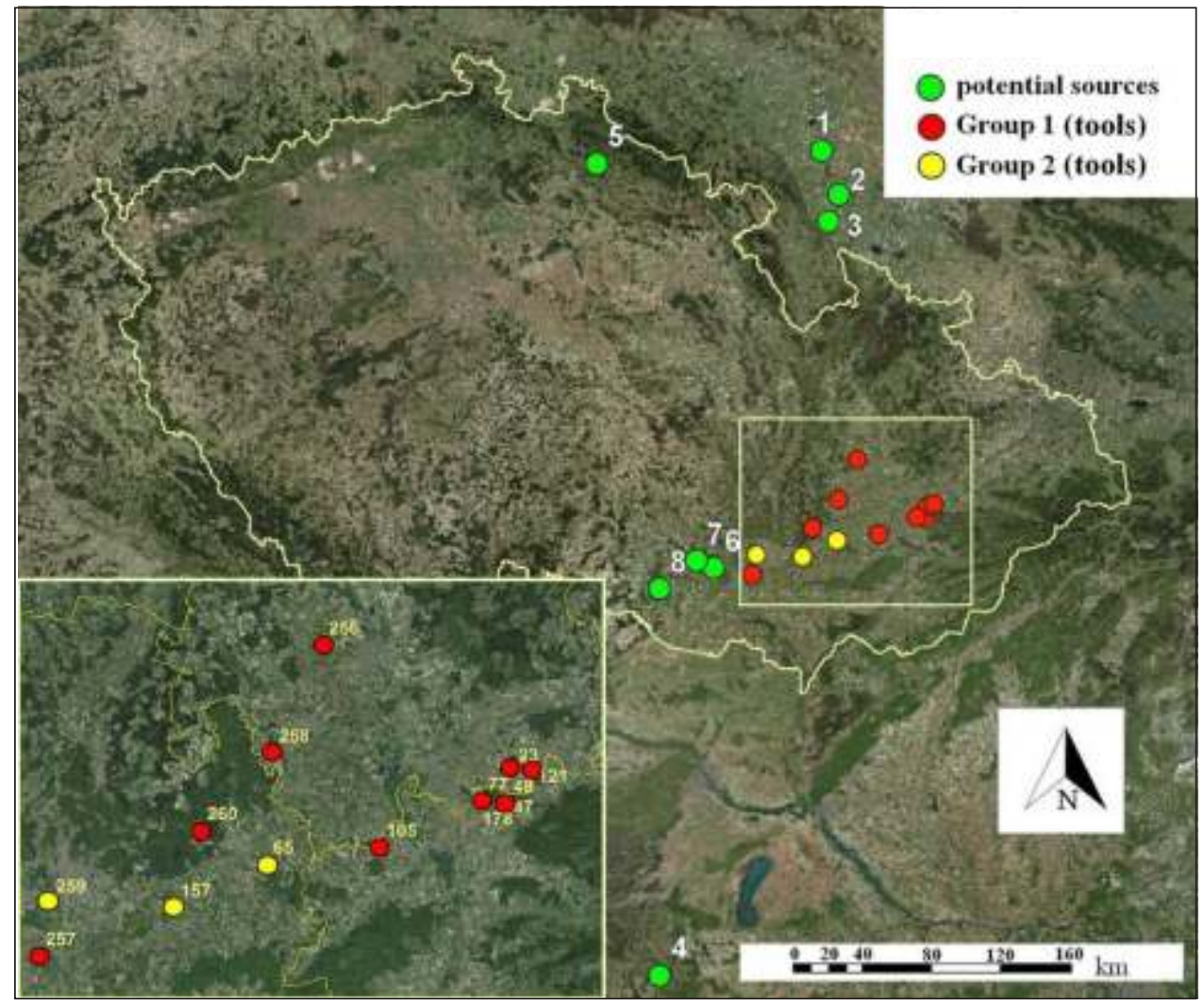

Fig. 2. Map of the archaeological sites and raw material sources (based on the map from the website: Mapy.cz 2017), modified to show localities

Potential sources: 1 - Gogołów-Jordanów Massif, 2 - Szklary Massif, 3 - Braszowice-Brzeźnica Massif, 4 - Penninic Bernstein Window (Bernstein, Rumpersdorf, Bienenhütte), 5 - Western Lugicum (Loužnice, Loužnice-Radčice, Alšovice, Klíčnov), 6 - Mohelno Massif, 7 - Hrubšice Massif, 8 - Gföhl Unit (Jevišovice district)

ing that all Fe is divalent. The chemical compositions of the spinels and amphibole are given in Appendix 2*.

The bulk-rock chemistry of pulverised samples was determined at the Bureau Veritas, Vancouver, Canada (formerly ACME Laboratories) using the ICP-ES after melting with lithium borate. Trace elements were analysed by the ICP-MS following a lithium tetraborate fusion. For comparison with the tools, only a limited number of elements can be determined, as only non-destructive methods could be used for the tools.

The powder X-ray diffraction (XRD) technique was used to determine mineral composition of the samples with respect to serpentine group minerals. Three bulk tools and 13 pulverised samples of serpentinites from source localities were analysed. XRD analyses were performed using a Rigaku Smartlab diffractometer with a parallel beam (bulk samples) and Bragg-Brentano (powder samples) $\theta-\theta$ reflection geometry. Ni-filtered Cu radiation $\left(\lambda \mathrm{K}_{\alpha}=0.15418 \mathrm{~nm}\right)$ was used. The tube was operated at $40 \mathrm{kV}$ and $30 \mathrm{~mA}$. An angular range of $5-80^{\circ} 2 \theta$ was measured. A step size of $0.02^{\circ} 2 \theta$ and time per step of $1 \mathrm{~s}$, which produces a total scan duration of $3750 \mathrm{~s}$, was used. The data obtained were evaluated with the help of the Panalytical High Score 3 Plus software. The quantitative phase analysis was performed by the Rietveld method. Crystal structure models from the ICSD 2012 database were used.
For the non-destructive measurements of tools and rock samples, a DELTA ED-XRF spectrometer with a $40 \mathrm{kV}$ tube and Si-PIN detector was used. The device was calibrated with a stainless steel calibration reference coin before the measurement. The measurements were made using the analytical Soil Geochem mode, which is able to analyse elements from trace amounts to high concentration levels. The duration of the measurement was set to $90 \mathrm{~s}$.

The magnetic susceptibility (MS) was measured using a portable KT-5 kappameter. Each sample was subjected to six independent measurements, the average value of these was then calculated. The resulting average was the measured magnetic susceptibility. The TCF of Williams-Thorpe et al. (2000) was applied.

\section{RESULTS}

\section{MAGNETIC SUSCEPTIBILITY}

The average value of both Group 1 and Group 2 varies around $40 \times 10^{-3} \mathrm{SI}$ units. The tools from Group 1 show a wider range of MS values while the tools from the Group 2 show a

\footnotetext{
* Supplementary data associated with this article can be found, in the online version, at doi: 10.7306/gq.1437
} 
lower variability of MS values. The higher values $\left(53-71 \times 10^{-3}\right.$ SI units) of MS were obtained from the tools from Syrovice, Blazice, Prusinovice (Group 1) and Boškůvky (Group 2).

Samples of serpentinites from potential sources in SW Poland have greater scattering of MS values (average 28-35 $\times$ $10^{-3} \mathrm{SI}$ units). Lower values $\left(20-24 \times 10^{-3} \mathrm{SI}\right.$ units) were yielded by samples with a weathered surface (Wiry, Sobótka, Jordanów). Higher values of MS (57-69 × $10^{-3}$ SI units) were measured on the samples from Jańska Góra and Brzeźnica.

Sources from Central Burgenland have generally lower values of MS (21-25 $\times 10^{-3}$ SI units), being only rarely significantly higher $\left(53 \times 10^{-3} \mathrm{SI}\right.$ units). The serpentinites of the Železný Brod crystalline unit (Jizera Mountains Piedmont) are characterized by predominantly very high values of MS (average $57 \times$ $10^{-3}$ SI units).

The Moldanubian serpentinites from the Jevišovice area have the lowest values of MS of all samples measured (average $7 \times 10^{-3} \mathrm{SI}$ units). Similarly, the values of the sources from around Hrubšice and Mohelno have relatively very low MS (average $11 \times 10^{-3} \mathrm{SI}$ units). The results of the basic statistical analysis from different raw material outcrops and tools are shown in Figure 3 and in Appendix 1.

\section{PETROGRAPHY AND MINERAL CHEMISTRY}

Based on macroscopic examination, the serpentinite tools were divided into two different groups and compared with each other. The typology of the individual tools and the occurrence of selected types (e.g., the so-called Ślę a type) in the vicinity of potential sources were also taken into account.

Group 1. The group comprises battle-axes from Zdětín, Syrovice, Prostějov, Ježkovice, Prusinovice, Dřevohostice, Blazice, Kostelec u Holešova and Zlobice. The battle-axes from Prostějov (Fig. 4A), Dřevohostice (Fig. 4B), Prusinovice no. 178, Ježkovice, Kostelec u Holešova and Zlobice have a simple shape in plane view with convex sides, while in side view they are trapezoid (Prostějov, Dřevohostice, Prusinovice no. 178), biconvex (Ježkovice), planoconvex (Kostelec u Holešova) or rectangular (Zlobice). The battle-axe from Prusinovice no. 178 has a damaged edge (Šebela, 1999). The battle-axe from Zdětín (Fig. 4C) is of pentagonal shape with facets in the butt

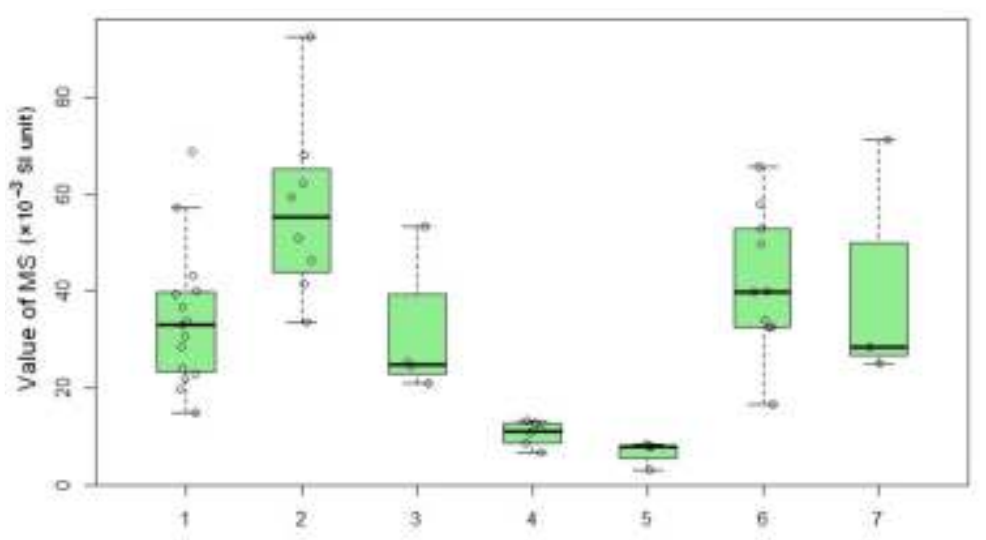

Fig. 3. Box plot of the magnetic susceptibility values of the raw materials from the potential sources and tools

1 - Lower Silesia, 2 - Western Lugicum (Jizera Mountains Piedmont), 3 Penninic Bernstein Window, 4 - Hrubšice and Mohelno massifs, 5 - Gföhl Unit (Jevišovice district), 6 - tools of Group 1, 7 - tools of Group 2 part in plan view. The battle-axe from Blazice has a simple shape broken at the bore with a secondary bore and the battle-axe from Syrovice is convexly bent with a downward extended edge and has a bore made from both sides situated near the butt (Šebela, 1999). The battle-axes from Prusinovice nos. 47 (Fig. 4D) and 48 are so-called battle-axes of the Ślę a type with footing. Battle-axe no. 47 is decorated (Šebela, 1999).

This group includes most of the tools with a greenish to dark grey patina on the surface. The structure is generally massive, sometimes with darker spots on the surface that may indicate foliation. The surface of the tools was often patinated, with slight crumblings tinted with limonite.

Group 2. The group comprises battle-axes from Brno-Starý Lískovec, Velešovice and Boškůvky. The battle-axes from BrnoStarý Lískovec (Fig. 4E) and Velešovice (Fig. 4F) have arch-like thickening in place of a bore in plan view with a rectangular cross-section in side view (Šebela, 1999). The battle-axe from Boškůvky has a simple shape with facets on the walls of the borehole, with traces of boring from both directions (Šebela, 1999).

The surface of these tools is shiny with solid grey-green to green-black hues, occasionally with a whitish-grey colour. The rock structure is massive or with thin darker streaking parallel to foliation. Slight crumblings tinted with limonite are developed on the surface of the battle-axe from Boškưvky.

\section{POTENTIAL SOURCE REGIONS}

Lower Silesia. Fresh rocks from the Gogołów-Jordanów and Braszowice-Brzeźnica Massifs are spotted (Fig. 5B, D-F), green to green-black with dark streaks parallel to foliation, and with macroscopically visible grains of magnetite in places. Where weathered, the surface is greenish grey-white with limonitic patches, caused by the staining of small crumblings on the surface by limonite (Fig. 5A, C). The rock-structure is massive.

The raw material from Gogołów-Jodanów Massif and Braszowice-Brzeźnica Massif looks similar using the polarizing microscope. The composition of the serpentinites from the Szklary Massif varies more in comparison. The rocks that form Szklary Massif yield poor-quality raw material, heavily weathered and usually tend to crumble due to pronounced tectonic disturbance. The rocks have a reddish surface covered by secondary minerals.

Jizera Mountains Piedmont (Western Lugicum). Dark green-black to dark grey-green rocks with massive structure, in which macroscopic pyroxene phenocrysts (up to $5 \mathrm{~mm}$ ) can be observed, were found in the vicinity of Železný Brod in the municipalities of Loužnice, Alšovice and Klíčnov. Pyroxenes commonly compose up to one quarter of the total volume of the whole rock.

Bernstein (Penninic Bernsten Window, Eastern Alps). The serpentinites are dark green with notable splinter facets of relic pyroxenes. Their structure is usually massive. Primary mineral relics or their pseudomorphs and a lower content of spinels are typically present.

Western Moravia - the Moravian Moldanubicum. The colour of the serpentinites from Hrubšice ranges from dark green-black to grey-green. The grey-green varieties contain grains of pyroxenes observable to the naked eye. Black grains of spinel with a metallic lustre and grains of rhombic pyroxene are visible macroscopically and the rock bears massive structure. 


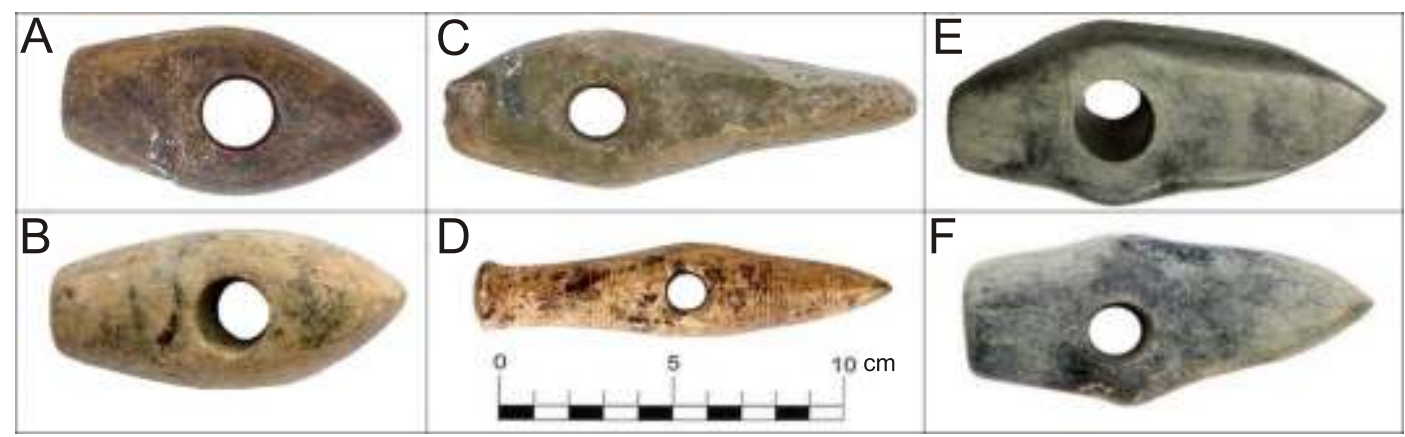

Fig. 4. Tools of Group 1: A - Prostějov, B - Zdětín, C - Dřevohostice, D - Prusinovice (no. 47); tools of Group 2: E - Brno-Starý Lískovec, F - Velešovice

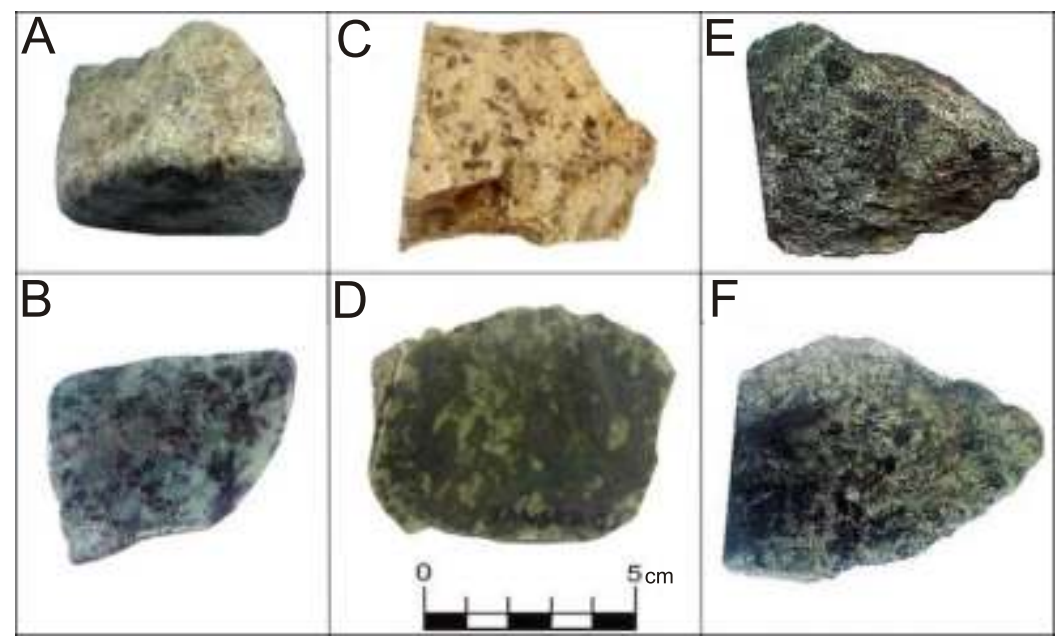

Fig. 5. The raw material from the Gogołów-Jordanów Massif
A - Tąpadła - patinated surface, B - Tapadła - fresh surface, C - Jańska Góra - patinated surface, D - Jańska Góra - fresh surface, E - Gogołów - patinated surface, F - Gogołów - fresh surface

The serpentinites from the Mohelno area are dark green to greenish-black. The rocks are obviously tectonically affected and strongly serpentinized. Their structure is massive. The microstructure is typically mesh-like. Serpentinites from the environs of Jevišovice are pale green on the surface, brownish-coloured locally (by extruded red iron-oxides) or dark green on the fresh surface. The rocks show intense tectonic disruption, which has caused cubiform disintegration.

The major mineralogical and petrographic data of the tools and of the raw material from the potential serpentinite sources is summarized in Table 3.

The raw materials of the tools from Group 1 often show a lepidoblastic and mesh-like microstructure when viewed using polarizing microscopy. The mesh-like microstructure is formed by minerals of the serpentine group, often with no relics of primary minerals except of the original pyroxene and olivine. Pseudomorphs are often filled with opaque minerals, which follow the original mineral cleavage (Fig. 6A). Red-brown grains of the lobe- or finger-shaped spinels are frequent (Fig. 6B), and carbonates are present occasionally. Large primary spinels, pseudomorphs filled with opaque minerals and locally present carbonates are typical of both groups. A mesh-like microstucture with no relics of olivines was observed in all samples from the Gogołów-Jordanów Massif (Fig. 6C). They contain lots of pseudomorphs filled with opaque phases, large lobe- or finger-shaped spinels (Fig. 6D), rarely carbonates and no pyrope. In the serpentinites from Western Lugicum, the Penninic Bernstein Window and Moravian Moldanubicum, relics of olivine, pyroxenes and secondary amphibole were observed (Fig. 6E, F).

The pseudomorphs filled with opaque minerals were found using EMPA in both of the tool Groups and in the raw material from the Lower Silesia (Fig. 7A, C). Also, large zoned primary spinels (Fig. 7B, D) and rarely carbonates are present. The classification of spinelides was taken according to Stevens (1944) as shown in the diagram of trivalent cations (Fig. 8). The primary spinels are strongly zoned. Two to three distinctive zones of different chemical composition were identified in zoned spinelides in both groups (Figs. 8 and 9). The content of $\mathrm{Fe}^{3+}$ predominates (74-97 mol.\%) at the periphery of grains relative to $\mathrm{Cr}$ content (3-24 mol.\%) corresponding to Cr-magnetite. A comparable proportion of $\mathrm{Fe}$ and $\mathrm{Cr}$ (41-59 mol.\%) was found in the transitional zone corresponding to Fe-chromite. The cores of grains are enriched in $\mathrm{Al}$ (39-55 mol.\%) which corresponds to Al-chromite and Cr-spinel. Magnetite (72-99 mol.\%) is the dominant component in unzoned secondary spinelides corresponding to Cr-magnetite. Significant zonation 
The major mineralogical and petrographic data of the tools and of the raw material from the serpentinite outcrops

\begin{tabular}{|c|c|c|c|c|c|c|c|c|c|c|c|}
\hline 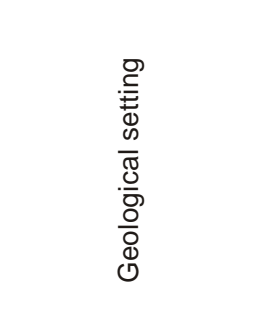 & 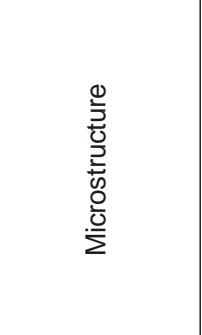 & 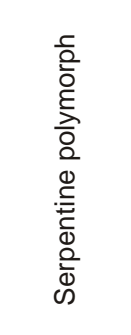 & 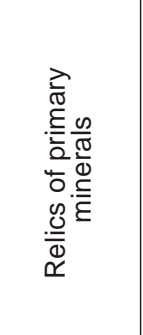 & 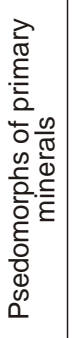 & 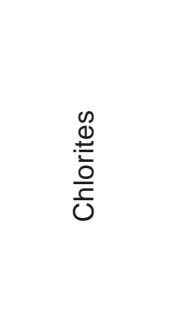 & 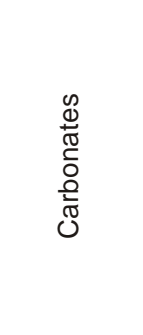 & 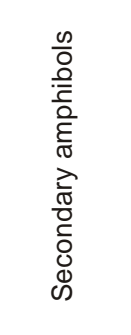 & 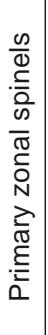 & 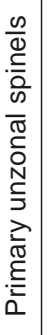 & 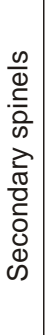 & 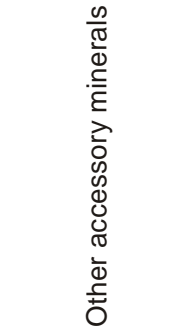 \\
\hline Group 1 & $\begin{array}{l}\text { mesh-like; } \\
\text { cross } \\
\text { filamentous }\end{array}$ & Atg \pm Ctl & & $\mathrm{x}$ & & Mag, Dol & & $x$ & & $x$ & \\
\hline Group 2 & mesh-like & Atg \pm Ctl & $x$ & $x$ & & Mag, Dol & $\operatorname{Tr}$ & $\mathrm{X}$ & & $x$ & \\
\hline $\begin{array}{l}\text { Gogołów- } \\
\text { Jordanów Massif }\end{array}$ & mesh-like & $\operatorname{Atg} \pm \mathrm{Lz}$ & & $x$ & & \pm Cal, Mag & & $x$ & & $x$ & \\
\hline $\begin{array}{c}\text { Braszowice- } \\
\text { Brzeźnica Massif }\end{array}$ & mesh-like & Atg $\pm \mathrm{Lz}$ & & $x$ & & & & $x$ & $x$ & $x$ & \\
\hline Szklary Massif & $\begin{array}{l}\text { mesh-like; } \\
\text { banded }\end{array}$ & Atg & Ol, Opx & $x$ & clinochlorite & $\mathrm{x}$ & Tr, Ath & & & $x$ & Czo \\
\hline Western Lugicum & poikilitic & Atg \pm Ctl & Di, Aug & & penninite & & Tr, Prg & $\mathrm{x}$ & & $x$ & $\begin{array}{l}\text { IIm, Ap, Zrn, } \\
\text { sulphides }\end{array}$ \\
\hline $\begin{array}{l}\text { Penninic Bernstein } \\
\text { Window }\end{array}$ & relic mesh-like & Atg $\pm \mathrm{Lz}$ & Opx & $x$ & clinochlorite & & & $x$ & $x$ & $\mathrm{x}$ & $\begin{array}{l}\text { Tlc, IIm, Ap, } \\
\text { Ttn, sulphides }\end{array}$ \\
\hline Hrubšice Massif & $\begin{array}{l}\text { mesh-like; } \\
\text { latticed }\end{array}$ & Atg & OI, Opx & $\mathrm{x}$ & $x$ & Cal, Dol & Ath, Ged & $x$ & & $x$ & \\
\hline Mohelno Massif & mesh-like & Atg \pm Ctl & Ol, En, Di & & $x$ & & $\mathrm{Tr}$ & $\mathrm{X}$ & & $x$ & Grt \\
\hline $\begin{array}{c}\text { Gföhl Unit } \\
\text { (Jevišovice district) }\end{array}$ & mesh-like & Atg & Ol & & $x$ & Mag, Cal & & $x$ & $x$ & $x$ & Ap \\
\hline
\end{tabular}

Ap - apatite, Atg - antigorite, Ath - anthophyllite, Aug - augite, Cal - calcite, Ctl -chrysotile, Czo-clinozoisite, Di-diopside, Dol-dolomite, En - enstatite, Ged - gedrite, Grt - garnet, Ilm - ilmenite, Lz - lizardite, Mag - magnetite, Ol - olivne, Opx - orthopyroxene, Prg - pargasite, Tlc - talc, Tr - tremolite, Ttn - titanite, Zrn - zircon

of spinelides was found in the raw material from Lower Silesia. The cores of spinelide grains from the Gogołów-Jodanów and Braszowice-Brzeźnica massifs have a high content of Al bound to the spinel component $(46-58 \mathrm{~mol} . \%)$ corresponding to $\mathrm{Cr}$ -spinel, in places to Al-chromite (Fig. 8). The content of $\mathrm{Cr}$ significantly increases in the transitional zone, binding to the chromite component (39-80 mol.\%) which corresponds to Fe-chromite. The periphery of zonal spinelides consists mainly of Fe bound to the magnetite component (77-100 mol.\%) corresponding to Cr-magnetite. Secondary spinelides, often developing along the shear planes, approach the composition of pure magnetite, with traces of $\mathrm{Cr}, \mathrm{Mg}$, and $\mathrm{Ni}$. The chemical composition and zonation of spinelides from the Gogołów-Jodanów and Braszowice-Brzeźnica massifs can be seen in diagrams of $\# \mathrm{Mg}=\mathrm{Mg} /\left(\mathrm{Mg}+\mathrm{Fe}^{+2}\right)$ vs. $\# \mathrm{Fe}^{3+}=\mathrm{Fe}^{3+} /(\mathrm{Cr}+\mathrm{Al}+$ $\left.\mathrm{Fe}^{3+}\right)$ and $\# \mathrm{Mg}$ vs. $\# \mathrm{Cr}=\mathrm{Cr} /(\mathrm{Cr}+\mathrm{Al})$ in Figure 9. The spinelides' composition varies directionally from the core to the periphery. In the Szklary Massif, no zonation of spinels was found. The magnetite component is predominant (75-81 mol.\%) in the measurable spinels. A relatively balanced ratio of magnetite (34-65 mol.\%) and chromite- (20-39 mol.\%) and spinel- components in the cores (up to $20 \mathrm{~mol} . \%$ ) was found in the spinelides from serpentinites of Western Lugicum (Figs. 8 and 9). By contrast, the magnetite component (97-99 mol.\%) predominates at the periphery of spinelide grains. Moreover, contents of $\mathrm{Ti}$ are elevated (0.07-0.15 apfu). The magnetite component prevails almost entirely (97-99 mol.\%) in secondary spinelides. Zonation was found also in primary spinelides from the serpentinites of Central Burgenland (Figs. 8 and 9). The rims of spinelide grains are Fe-rich (96-99 mol.\%) relative to
Cr-content (1-4 mol.\%) in contrast to Cr-enriched cores (47-49 mol.\%), while the Fe- and Al-contents ratios are close (25-27 mol.\%). The magnetite component predominates in unzoned secondary spinelides (93-99 mol.\%). Zoned spinelides are present in the serpentinites from the Jevišovice area. The magnetite component predominates in the unzoned secondary spinelides (99-100 mol.\%), corresponding to $\mathrm{Cr}$-magnetite and in primary spinelides $\mathrm{Cr}$ predominates (43-65 mol.\%), corresponding to Al-chromite. A different type of zoned spinel was found in the serpentinites from Hrubšice. The content of Al predominates in the cores (71-75 mol.\%), corresponding to $\mathrm{Cr}$ -spinel. The content of $\mathrm{Fe}$ is dominant at the periphery of zoned spinelides (92 mol.\%), thus placing it within Al-magnetite.

Primary amphiboles were identified using EPMA only in the raw material of the tool from Brno-Starý Lískovec among the tools studied (Group 2). The composition of the amphiboles corresponds to Ca-amphiboles (tremolite) shown in Figure 10. Fe-Mg-Mn amphiboles (antophyllite) and Ca-amphiboles (tremolite) were found in the serpentinite of the Szklary Massif. Primary pyroxenes (diopside, augite) and secondary calcic amphiboles (tremolite-pargasites) were detected in serpentinites from the Jizera Mountains Piedmont. No measurable relics of primary minerals were found in serpentinites from the Bernstein area (Fig. 7E). Ca-amphiboles (pargasites) were identified in the serpentinites from the Jevišovice area (Fig. 7F). Serpentinites from Hrubšice contained secondary Fe-Mg-Mn amphiboles corresponding to the anthophyllite-gedrite series. The chemical composition of amphiboles from the raw materials of the tools and of the sources can be found in Figure 10 and Appendix 2. 


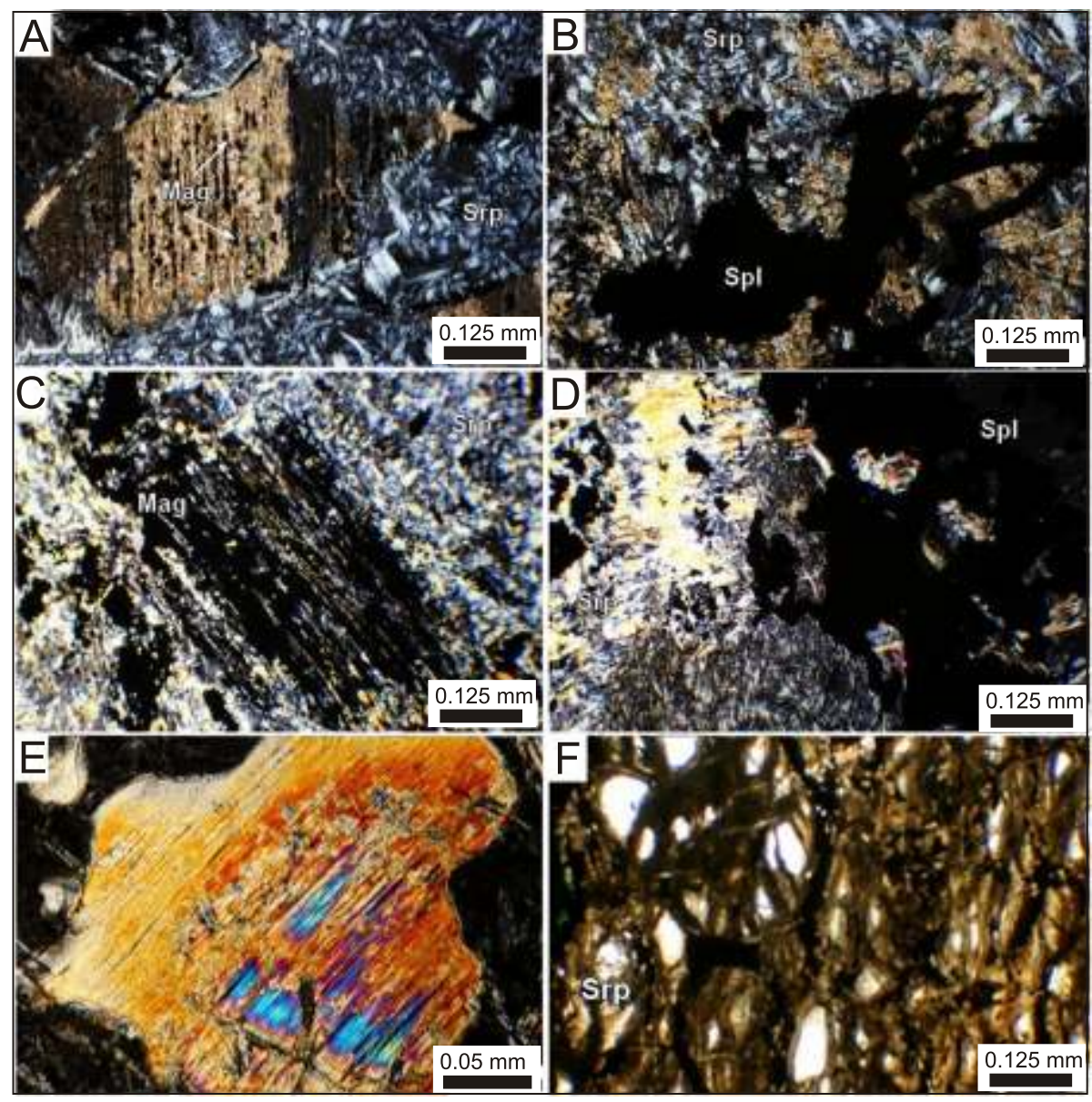

Fig. 6. Rock microstructures of the battle-axe from Prostějov and the samples from the potential raw material sources in thin-section

A, C - pseudomorphs after primary minerals filled with opaque minerals ( $A$ - battle-axe from Prostějov; C - Jańska Góra in the Gogołów-Jordanów Massif); B, D - zoned spinels (B - battle-axe from Prostějov; D - Tąpadła in the Gogołów-Jordanów Massif); $\mathbf{E}$ - relic of primary mineral (Bernstein 1 in the Penninic Bernstein Window); F - rock microstructure (Bojanovice in the Gföhl Unit, Jevišovice district); Mag - magnetite, Spl - spinel, Srp - serpentine

\section{BULK-ROCK CHEMISTRY (ICP, XRF)}

After comparing results obtained from both the ICP- and XRF-methods, a good degree of conformity was found among selected elements and is documented in the plot in Figure 11. The samples from Lower Silesia and the tools' raw material of both Groups were Mg-rich [Mg/(Mg + $\left.\mathrm{Fe}^{t}\right)=75-87$ wt.\%]. Samples from Western Lugicum were Fe-rich $\left[\mathrm{Mg} /\left(\mathrm{Mg}+\mathrm{Fe}^{t}\right)=\right.$ 55-61 wt.\%]. Serpentinites from western Moldanubicum were generally $\mathrm{Mg}$-richer $\left[\mathrm{Mg} /\left(\mathrm{Mg}+\mathrm{Fe}^{t}\right)=73-80\right.$ wt.\%] and raw material from Bernstein Window was predominantly Fe-rich $\left[\mathrm{Mg} /\left(\mathrm{Mg}+\mathrm{Fe}^{\mathrm{t}}\right)=57-63 \mathrm{wt} . \%\right]$, the exception being the sample from Bernstein $2\left[\mathrm{Mg} /\left(\mathrm{Mg}+\mathrm{Fe}^{t}\right)=76\right.$ wt.\%]

Major oxide and selected trace elements $(\mathrm{Ni}-, \mathrm{Zr}$ - and Sr-concentrations) of the potential source localities are given in Appendix 3.

\section{XRD ANALYSES}

The comparison of diffraction patterns is given in Figure 12. The XRD was performed on the surfaces of the bulk tools, which were patinated. The main goal of XRD analysis was to indentify serpentine mineral group species and to quantify their contents. The battle-axes are made of antigorite serpentinites. All the samples analysed contained various quantities of antigorite. In the samples from Braszowice, Tapadła 2, Loužnice and Bernstein 2, lizardite was also present. In these samples, lizardite was always less abundant that antigorite. The total contents of serpentine minerals ranged from $25.8 \%$ (Loužnice) $99.9 \%$ (Tapadła 2). The individual contents of serpentine group minerals are given in Figure 13. An overview of quantitative phase analysis is shown in Appendix 4.

\section{DISCUSSION}

\section{MOST PROBABLE PROVENANCE OF THE STONE TOOLS}

The macroscopic appearance of the tools of Group 1 corresponds to the raw material from Lower Silesia (patina with slight crumblings tinted with limonite on the surface, massive structure). Group 2 also features similar to those of the raw material from SW Poland. The tool raw material of Group 1 (Fig. 4A-D) is macroscopically quite similar to the raw materials of the localities Tapadła and Jańska Góra from the Gogołów-Jordanów 

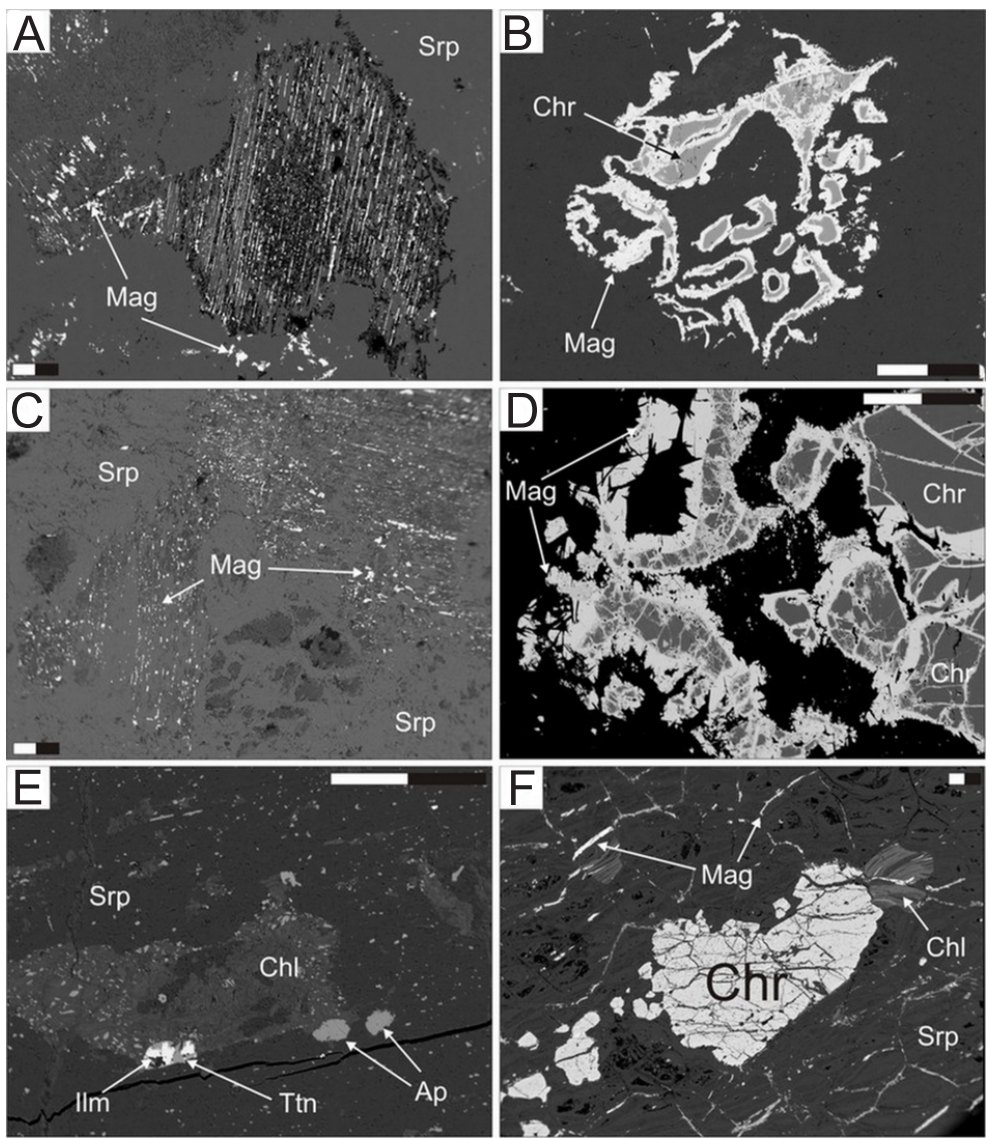

Fig. 7. Back-scattered electron (BSE) images of rock microstructures of the battle-axe from Prostějov and of samples from the potential raw material sources

A, C - pseudomorphs after primary minerals filled with opaque minerals ( $A$ - battle-axe from Prostějov; C - Jańska Góra in the Gogołów-Jordanów Massif); B, D - zoned spinels (B - battle-axe from Prostějov; D - Tapadła in the Gogołów-Jordanów Massif); E, F - rock microstructure (E - Bernstein 1 in the Penninic Bernstein Window; F - Bojanovice in the Gföhl Unit, Jevišovice district); Chl chlorite, $\mathrm{Chr}$ - chromite; scale bar $=200 \mu \mathrm{m}$

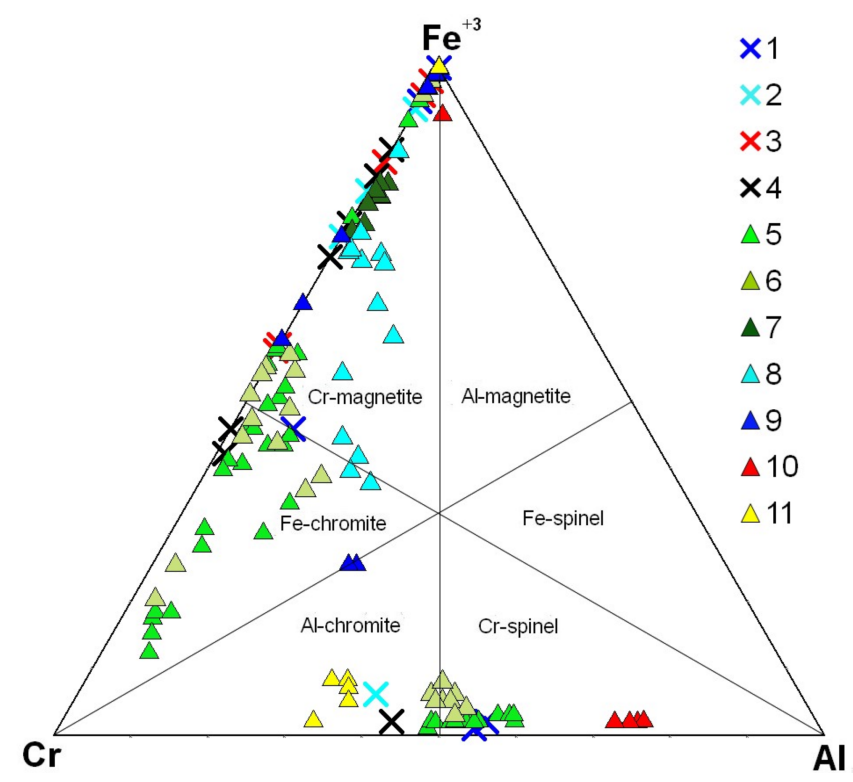

Al
Massif (Fig. 5A-D). The tools of Group 2 (Fig. 4E, F) are similar to the raw material from Gogołów in the Gogołów-Jordanów Massif (Fig. 5E, F). Kufel-Diakowska and Skuła (2015) described a stone shaft-hole axe from the younger phase of the CWC, found in a grave at Brożec. The shaft-hole axe described is macroscopically identical to the raw material of Group 1. This type of raw material is in the author's considered view typical for the region of southern Poland. In the case of battle-axes nos. 47 and 48 from Prusinovice, the provenance is supported by the typological likeness to the battle-axe of Ślęża type.

Fig. 8. The zonation of the spinelides from the potential raw material sources (triangles) and both tool Groups (crosses) in the diagram of trivalent cation ratios (according to Stevens, 1944, edited)

1 - Prostějov, 2 - Zdětín, 3 - Ježkovice, 4 - Brno-Starý Lískovec, 5 - Gogołów-Jordanów, 6 - Braszowice-Brzeźnica, 7 - Szklary, 8 Western Lugicum (Jizera Mountains Piedmont), 9 - Penninic Bernstein Window, 10 - Hrubšice and Mohelno massifs, 11 - Gföhl Unit (Jevišovice district) 

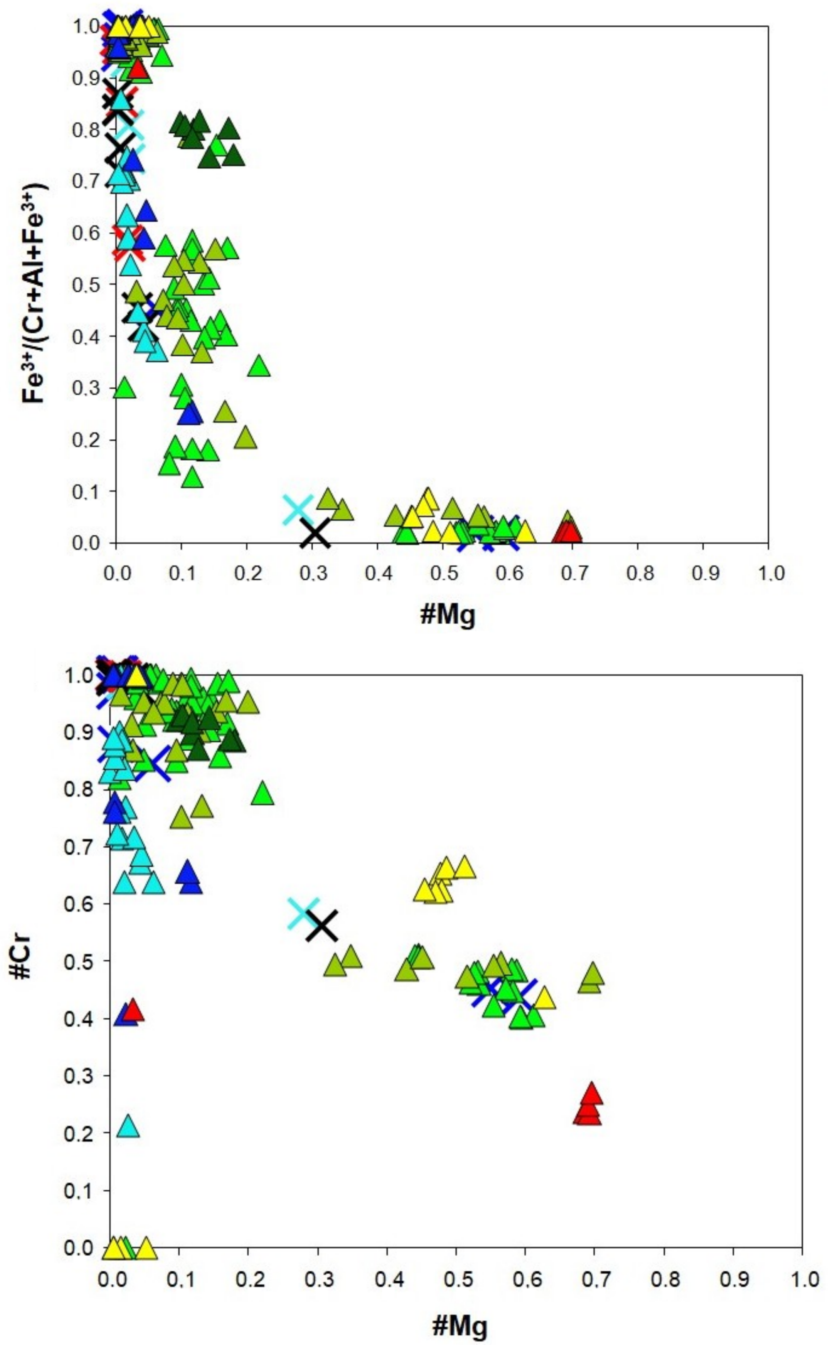

Fig. 9. Compositional variations of the spinelides from the potential raw material sources and both tool Groups in the diagram $\mathrm{A}-\# \mathrm{Mg}$ vs. $\mathrm{Fe}^{3+} /\left(\mathrm{Cr}+\mathrm{Al}+\mathrm{Fe}^{3+}\right)$ and $\mathrm{B}-\# \mathrm{Mg}$ vs. \#Cr

For other explanations see Figure 8

Fig. 11. The bulk-rock chemistry of the raw materials from the potential source areas (triangles - ICP data, squares - XRF data) and of the raw material of the tools from Groups 1 and 2 (crosses)

A - plot of wt. $\% \mathrm{SiO}_{2}$ versus ratio $\mathrm{Mg} /\left(\mathrm{Mg}+\mathrm{Fe}^{\mathrm{t}}\right) ; \mathbf{B}$ - plot of wt. $\%$ $\mathrm{Cr}_{2} \mathrm{O}_{3}$ versus $\mathrm{Fe}_{2} \mathrm{O}_{3} ; 5-7$ - Lower Silesia (Gogołów-Jordanów, Braszowice-Brzeźnica and Szklary massifs), 8 - Western Lugicum (Jizera Mountains Piedmont), 9 - Penninic Bernstein Window, 10 Hrubšice Massif (Hrubšice, Biskoupky; Kudělásek, 1965), 11 Gföhl Unit (Jevišovice district), 12 - Mohelno Massif (Kudělásek, 1965; Kudělásková, 1972). Colours of ellipses correspond to colours of potential sources used in the legend $(5,6,7$ - green, 8 azure blue, 9 - blue, 10-12 - red)
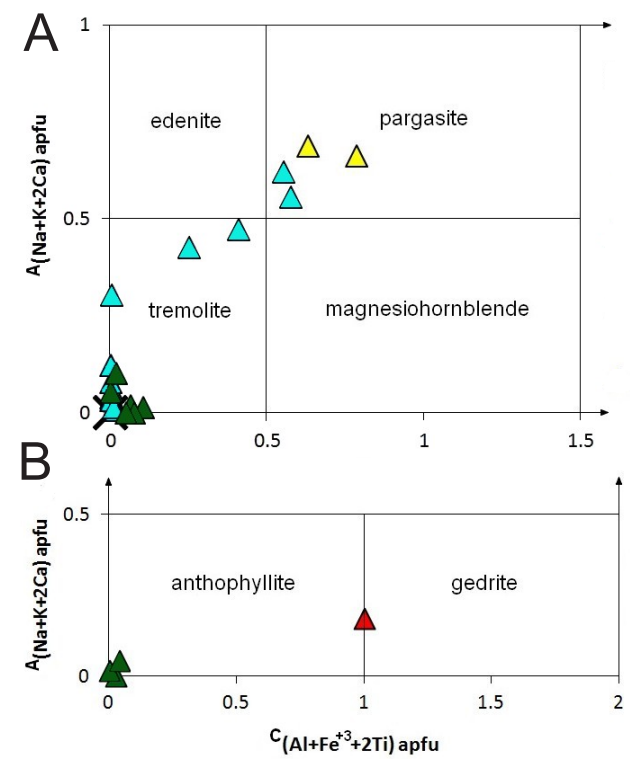

Fig. 10. Composition of amphiboles from the potential raw material sources and from the tool from Brno-Starý Lískovec in the classification diagram of amphiboles (Hawthorne et al., 2012, edited)

A - Ca-amphiboles; $\mathbf{B}$ - Fe-Mg-Mn amphiboles; for other explanations see Figure 8

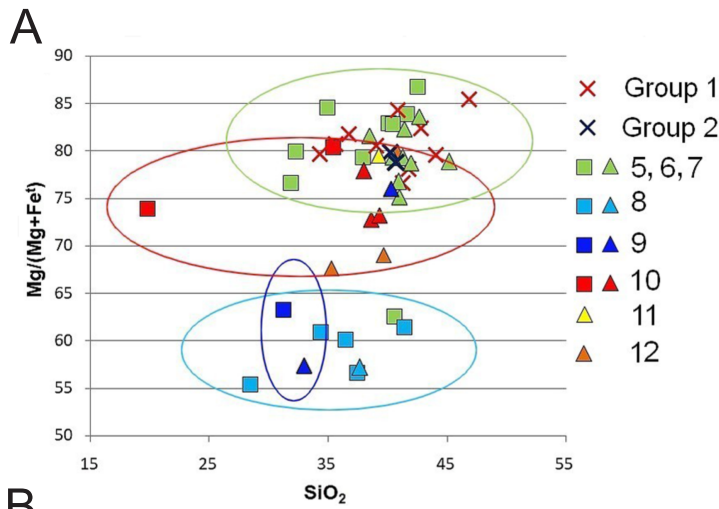

B

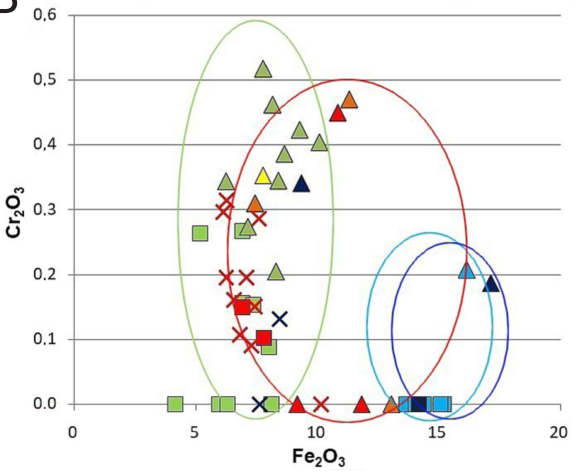



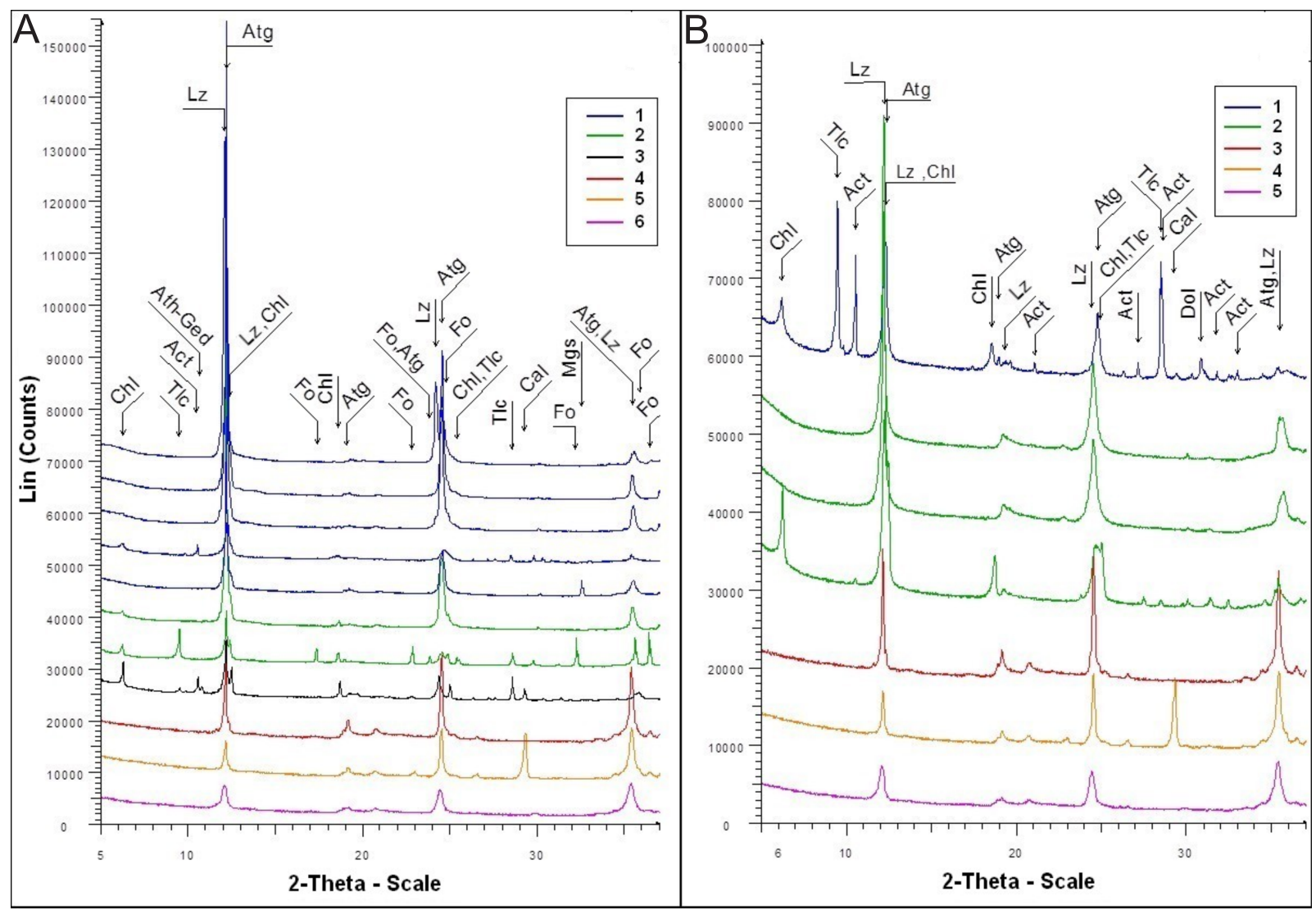

Fig. 12. Comparison of XRD-data of the tools and the potential raw material sources

A - serpentinite battle-axes and sources from Lower Silesia; potential sources: 1 - Gogołów-Jordanów Massif, 2 - Braszowice-Brzeźnica Massif, 3 - Szklary Massif; tools: 4 - Zdětín, 5 - Syrovice, 6 - Prostějov; B - serpentinite battle-axes and sources from the Penninic Bernstein Window and Western Lugicum; potential sources: 1 - Western Lugicum (Jizera Mountains Piedmont), 2 Penninic Bernstein Window; tools: 3 - Zdětín, 4 - Syrovice, 5 - Prostějov

Comparison of the values of magnetic susceptibility (MS) obtained from the both tool Groups and the raw materials from the potential sources supports the provenance of the tools' raw material being in Lower Silesia. The higher values obtained on some tools (Syrovice, Blazice, Boškůvky) also occur in some raw material from Lower Silesia (Jańska Góra, Brzeźnica). The Moldanubian sources have relatively low magnetic susceptibility compared with the raw material of the tools. The serpentinites from the Jizera Mountains Piedmont have a predominatly higher MS and sources from Central Burgenland have generally lower values of MS than the tools of both Groups.

On the basis of the petrography and mineral chemistry, there is an evident similarity in the raw material of Groups 1 and 2 to the raw material from Lower Silesia. The strong serpentinisation, low content of relics of primary minerals, pseudomorphs filled with secondary spinels and the occurrence of zoned spinels in the raw material of both tool Groups are similar to the sources from Lower Silesia. The zoned spinels show up to three zones of different composition, where chromite or even spinel components increase towards the core, and conversely the magnetite component grows towards the periphery. The zonation of the spinelides of the Group 2 spinels is less distinct and rather diffuse compared to that of Group 1. The raw material from Lower Silesia is significantly similar to the raw material of both Groups in the zonation of the spinelides. The data obtained from spinels of the Gogołów-Jodanów and Braszowice-
-Brzeźnica massifs and both tool Groups correspond to the findings of Kaqdziałko-Hofmokl et al. (2008), dealing with the mineralogy and magnetism of $\mathrm{Fe}-\mathrm{Cr}$ spinels from chromite and dunite lenses at the locality of Tapadła which occasionally occur in the serpentinite mass. These conclusions are supported by comparison with the results of the bulk chemistry from the sources and tools. As opposed to the raw material of the tool Groups in the serpentinites from the other probable sources (Western Lugicum, Penninic Bernstein Window, Moravian Moldanubicum) primary minerals or their relics are always preserved. In the raw material of the tools, measurable relics of primary minerals were found only in the battle-axe from Brno-Starý Lískovec (Group 2). Their composition corresponded to that of the serpentinites from the Szklary Massif. In serpentinites from the Jizera Mountains Piedmont, primary pyroxenes were detected. This is consistent with the serpentinites from this site not matching, as raw material, the tools of Groups 1 or 2; it is similar for the serpentinites from the Jevišovice area and the Hrubšice Massif in the Moravian Moldanubicum. In the serpentinites from the Bernstein area, many relics of primary minerals were detected, which does not correspond to the raw material of the tools of Groups 1 or 2.

These conclusions from the petrography and mineral chemistry are supported by the comparison with the results of the bulk-rock chemistry from the sources and tools. In the binary diagrams it is evident that the tools of both Groups indicate the 


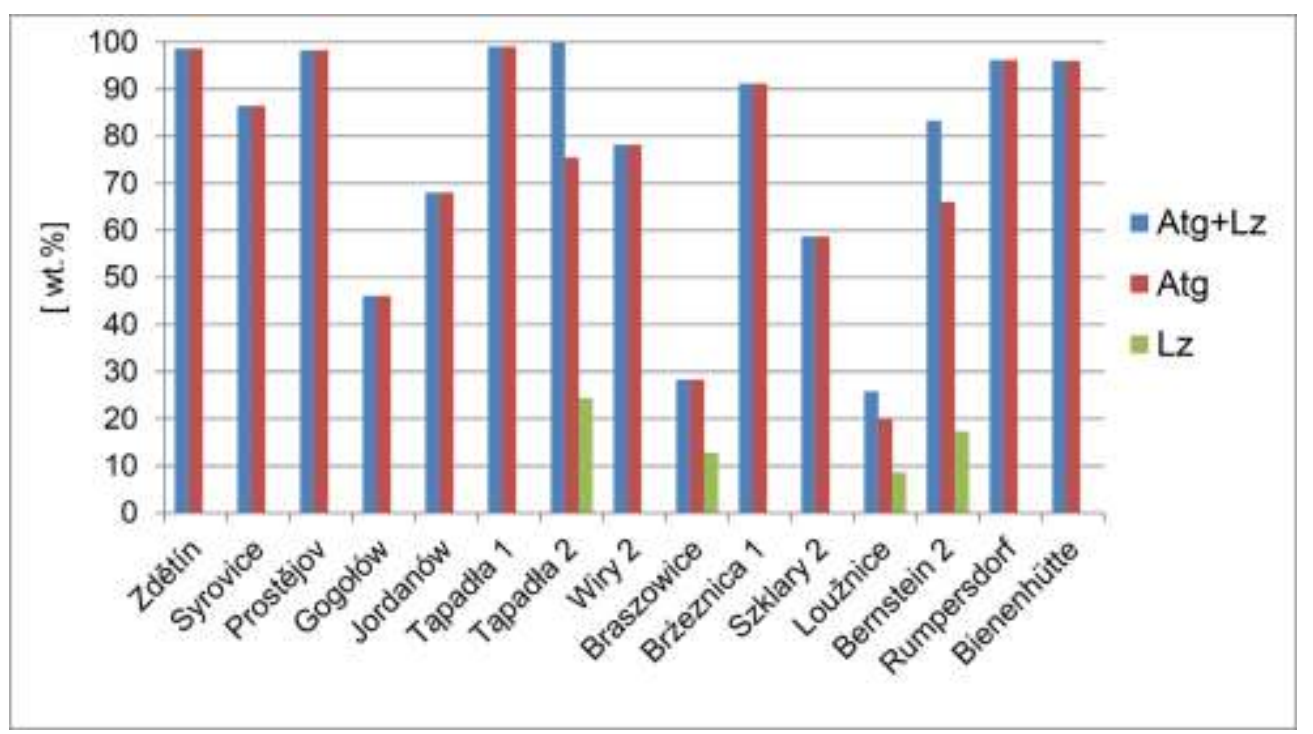

Fig. 13. Contents of serpentine group minerals in three CWC battle-axes from Moravia (Zdětín, Syrovice, Prostějov) and in various serpentinite sources of central Europe (the estimations are based on XRD analysis)

sources in Lower Silesia. By contrast, the sources from the Jizera Mountains Piedmont and the Bernstein area are significantly distinct. The serpentinites from the Moravian Moldanubicum (Jevišovice district, Hrubšice and Mohelno massifs) do not show a significant difference from the sources in Lower Silesia. Based on the results of the other methods used, it was, however, established that the tools of neither Groups correspond with these sources. One of the samples from the Bernstein area (Bernstein 1) has a different chemical composition (from ICP) than other samples from this area. In the diagram some values of this sample are similar to the values of the tools, but the results of further analyses (EMPA, ICP, MS) do not support the possibility of provenance in this area.

In the tools of Group 1 (battle-axes from Prostějov, Zdětín, Syrovice) antigorite, magnetite and spinel (in the battle-axe from Syrovice also calcite) were detected. In the samples of Lower Silesia, antigorite and magnetite were detected in all samples and in the samples from Gogołów and Wiry 2 carbonates (magnesite) were also found. In some samples chlorite, lizardite and amphiboles were also detected. The samples from Braszowice and Szklary 2 showed more varied composition than other samples.

Compared with the tools of Group 1, the samples from Western Lugicum had a different composition. The main components of the samples are chlorite, talc and antigorite. There is a smaller amount of amphibole, lizardite and dolomite. Accessory calcite and magnetite are also present. The sample Bernstein 2 also had a different composition, where antigorite, lizardite, chlorite and magnetite were detected. The other samples from the Pennninic Bernstein Window (Rumpersdorf, Bienenhütte) looked somewhat similar to the tools, but the results of the other analyses used (EMPA, ICP, XRF, MS) does not support this similarity.

It can be concluded that the mineral composition detected by XRD analyses (Fig. 12) corresponds with the composition found by studying thin-sections under a polarizing microscope. Compared to the composition determined by the study of thinsections under the polarizing microscope, in the tools from Prostějov and Zdětín, carbonates were found. This could be because XRD was applied only on the surface of the bulk tools, not on the pulverised samples. The samples from Lower Silesia revealed antigorite and antigorite-lizardite serpentinites. Antigorite and antigorite-lizardite is also found at the Bernstein and Loužnice sites. The tools were made of antigorite serpentinites.

The most probable source of the raw material of the tools of Group 1 and Group 2 used by the Corded Ware culture supposedly came from the Gogołów-Jordanów serpentinite Massif in Lower Silesia. Sources from Western Lugicum and the Pennninic Bernstein Window can be excluded, based on the findings of magnetic susceptibility and chemical composition. The Moldanubian sources can be excluded based on chemical and petrographic investigation and due to their low magnetic susceptibility compared with the tools. Other sources seem unlikely, especially in view of the EMPA analysis. In view of the EMPA analysis, sources near Hrubšice and Mohelno can also be excluded, due to the pronounced tectonic disruption and low magnetic susceptibility. Sources in the Jevišovice environs were characterized by the occurrence of siliceous weathered serpentinites that were exploited during the Neolithic period. Their presence indicates the weathering of the rock massif to a depth of several metres and the impossibility of obtaining high-quality raw materials directly at the surface. A final comparison is shown in the Table 4, which includes the results of the analyses of the battle-axes of the Corded Ware culture and their possible provenance.

\section{CONCLUSIONS}

Our comparison of serpentinite tools from Groups 1 and 2 with the raw materials of potential source areas is based on macroscopic and petrographic descriptions, investigation of the rock-forming minerals using EMPA, determination of chemical composition and measurement of magnetic susceptibility. It supports the idea that the place of origin of the raw material used for the CWC battle-axes found in Moravia lay in Lower Silesia, SW Poland. For some battle-axes (Prusinovice nos. 47 and 48 ) this fact is underlined also by the typological links between the raw material and the battle-axe of Ślę a type, docu- 


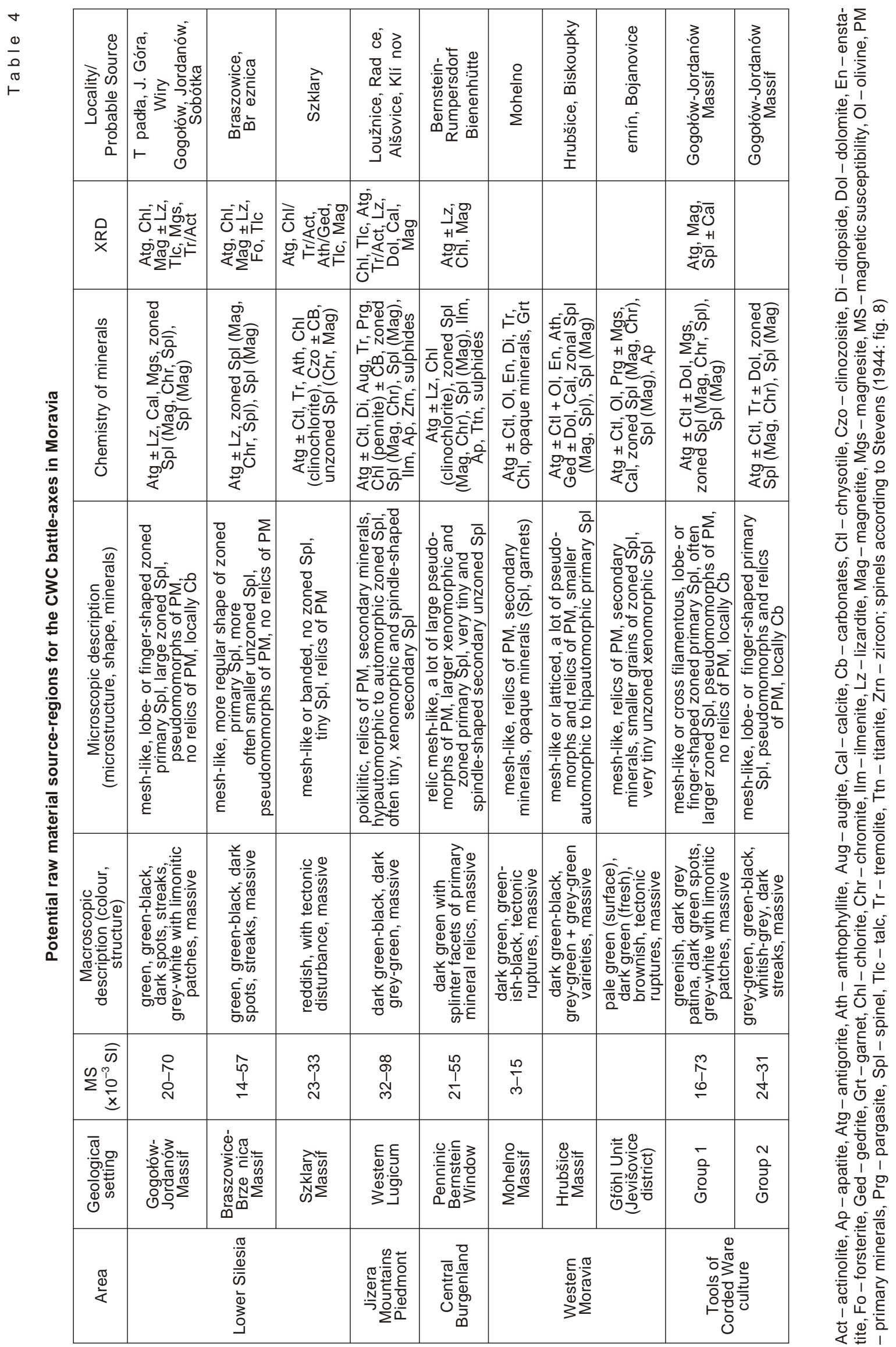


mented from the provenance area around Mount Śle a. Because there is also archaeological evidence from Poland of Eneolithic mining in the Gogołów-Jordanów Massif (Wojciechowski, 1983, 1988), it can be concluded that the source area for these tool groups was indeed this massif.

The analyses undertaken have shown that the main characteristics of serpentinites from Lower Silesia and the raw material of Groups 1 and 2 are very strong serpentinisation, low to almost no presence of relics of the primary minerals (featuring only pseudomorphs filled with secondary spinels), and the local occurrence of carbonates, mainly spinels. The spinels often occur as zoned primary spinels with their composition changing directionally from the core to the periphery and as secondary unzoned spinels of uniform composition. The zoned spinels show up to three zones of different composition, where towards the core we see an increasing chromite or even spinel component and conversely towards the periphery a higher content of magnetite component. The variability in the chemical composition of spinels is also apparent in Figures 8 and 9.

Our current knowledge (including newly ascertained data for raw material of artefacts) and comparison with serpentinites from different parts of Central Europe (Gogołów-Jordanów Massif in Lower Silesia, Penninic Bernstein Window in Central Burgenland, Železný Brod crystalline unit in northern Bohemia and Moldanubicum of western Moravia) have shown that the raw materials for the production of serpentinite tools of the CWC in Moravia and Czech Silesia originate from the Gogołów-Jordanów Massif. From there, the mining and usage of its serpentinites (Wojciechowski, 1983, 1988) and their distribution throughout Poland (Skoczylas et al., 2000) are described. In their features the tools match the presumed source in the Gogołów-Jordanów Massif. The analyses indicated investigation of spinels and relics of the primary minerals to be most important. The microprobe results were also in accordance with measurements using non-destructive techniques and with the typological connections of some tools to Lower Silesia. Thus, these results support the previously published conclusions of Prichystal and Šebela (1992).

Acknowledgements. The research has been supported by the MSM 0021622427 "Interdisciplinary Centre for Research of Social Structures from Prehistory to Late Middle Ages" research project. We would like to thank Doc. M. Gregerová for consultations during the petrographic investigation of thin-sections and the reviewers, Doc. L. Illášová, Ass. Prof. G. Szakmány, Dr. P.M. Wojtulek and an anonymous reviewer, for constructive comments and suggestions which were helpful in preparing the final version of the paper. Special thanks to the editor Prof. T.M. Peryt for his valuable comments and help.

\section{REFERENCES}

Baldia, M.O., Frink, D.S., Boulanger, M.T., 2008. Problems; in the archaeological legacy: the TRB/Lengyel-Baden comlex. Studien zur Archäologie in Ostmitteleuropa, 4: 25-49.

Bernard, J.H., Čech, F., Dávidová, Š., Dudek, A., Fediuk, F., Hovorka, D., Kettner, R., Koděra, M., Kopecký, L., Němec, D., Paděra, K., Petránek, J., Sekanina, J., Staněk, J., Šímová, M., 1981. Mineralogie Československa (in Czech). Academia, Praha.

Bernardini, F., De Min, A., Eichert, D., Alberti, A., Demarchi, G. Velušček, A., Tuniz, C., Kokelj, E.M., 2010. Shaft-hole axes from Caput Adriae: mineralogical and chemical constraints about the provenance of serpentinitic artefacts. Archaeometry, 53: 261-284

Biró, K.T., Szakmány, Gy., 2000. Current state of research on Hungarian Neolithic polished stone artefacts. Krystalinikum, 26 21-37.

Chmielewski, T.J., Romanow, J., 2015. Pozostałości kurhanu odkryte na stanowisku 6 w Wysokiej, gm. Kobierzyce. Przyczynki do badań nad kulturą ceramiki sznurowej na Nizinie Śląskiej (in Polish). Śląskie Sprawozdania Archeologiczne, 57: 31-64.

Dubińska, E., Gunia, P., 1997. The Sudetic ophiolite: current view on its geodynamic model. Geological Quarterly, 41 (1): 1-20.

DunkI, I., Demény, A., 1997. Exhumation of the Rechnitz Window at the border of the Eastern Alps and Pannonian Basin during Neogene extension. Tectonophysics, 272: 197-211.

Evans, B.W., Hattori, K., Baronnet, A., 2013. Serpentinites: what why, where? Elements, 9: 99-106.

Fediuk, F., 2006. Komatiit-mejmečitová povaha ultrabazik železnobrodského krystalinika (in Czech). Zprávy o Geologických Výzkumech v Roce 2005, 39: 109-110.

Grömer, K., 2002. Das Neolithikum im Oberösterreichischen Mühlviertel. Archeologické výzkumy v jižních Čechách, 15: 7-54

Guillot, S., Hattori, K., 2013. Serpentinites: essential roles in geodynamics, arc volcanism, sustainable development, and the origin of life. Elements, 9: 95-98.
Gunia, P., 1988. Deformation-recrystallization structures of olivines in ultrabasites of the Braszowice-Brzeźnica Massif (Lower Silesia). Mineralogia Polonica, 19: 71-90.

Gunia, P., 1992. Petrology of the ultrabasic rocks from the Braszowice-Brzeźnica massif (Fore-Sudetic Block). Geologica Sudetica, 26: 120-178.

Gunia, P., 1993. Remarks about serpentinite structures from Szklary massif (Fore-Sudetic block). Polish Mineralogical Society Special Papers, 4: 78-80.

Gunia, P., 1995. Petrology and geochemistry of the metabasic rock from the Szklary Massif (Fore-Sudetic Block, SW Poland). Bulletin of the Polish Academy of Sciences, Earth Sciences, 43 123-135.

Gunia, P., 2000. The petrology and geochemistry of mantle-derived basic and ultrabasic rocks from the Szklary massif in the Fore-Sudetic Block (SW Poland). Geologia Sudetica, 33: 71-83.

Hawthorne, F.C., Oberti, R., Harlow, G.E., Maresch, W.V., Martin, R.F., Schumacher, J.C., Welch, M.D., 2012. IMA Report: nomenclature of the amphibole supergroup. American Mineralogist, 97: 2031-2048.

Hejtman, B., 1962. Petrografie metamorfovaných hornin (in Czech). Nakladatelství ČSAV, Praha.

Kądziałko-Hofmokl, M., Delura, K., Bylina, P., Jeleńska, M. Kruczyk, J., 2008. Mineralogy and magnetism of Fe-Cr spine series minerals from podiform chromitites and dunites from Tapadła (Sudetic ophiolite, SW Poland) and their relationship to palaeomagnetic results of the dunites. Geophysical Journal International, 175: 885-900.

Koller, F., 1985. Petrologie und Geochemie der Ophiolite des Penninikums am Alpenostrand. Jahres Buch der Geologischen Burdesanstalt, Wien, 128: 83-150.

Kryza, R., Pin, C., 2010. The Central-Sudetic ophiolites (SW Poland): petrogenetic issues, geochronology and palaeotectonic implications. Gondwana Research, 17: 292-305.

Kudělásek, V., 1965. Comparaison du chimisme de certaines ultrabasites moldanubiennes. Geochemie v Československu, 
Sborník prací 1. Geochemické konference v Ostravě, 1965: 47-65.

Kudělásková, M., 1972. Chemismus některých granátických serpentinitů moravské části moldanubika (in Czech). Sborník Vědeckých Prací Vysoké Školy Báňské v Ostravě, Řada Hornicko-geologická, 18: 113-120.

Kufel-Diakowska, B., Skuła, M., 2015. Life and afterlife of tools: Axes of the Corded Ware culture in morpho-functional analysis. Sprawozdania Archeologiczne, 67: 57-65.

Majerowicz, A., Pin, C., 1989. Recent progress in petrologic study of the Ślę a ophiolite complex. In: Lower and Upper Paleozoic metabasites and ophiolites of the Polish Sudetes. Guidebook of Excursions in Poland, May 1989 (eds. W. Narębski and A. Majerowicz): 34-72. Polish Academy of Sciences, Wrocław.

Majerowicz, A., Pin, C., 1994. The main petrological problems of the Mt. Slę a ophiolite complex, Sudetes (Poland). Zentralblatt für Geologie und Paläontologie, 2: 989-1018.

Majerowicz, A., Wojcik, A., Gunia, P., Cholewa, P., 2000. Comparative study of serpentinite textures and rock material of Neolithic artefacts from Lower Silesia (SW Poland). Krystalinikum, 26: 111-117.

Mallory, J.P., Adams, D.Q., 1997. Encyclopedia of Indo-European Culture. Fitzroy Dearborn Publishers, London-Chicago.

Mazur, S., Puziewicz, J., 1995. Deformation and metamorphism of rock series east of the Sowie Góry Block - new data and interpretations (in Polish with English summary). Przegląd Geologiczny, 43: 786-73.

Mrázek, I., Rejl, L., 1991. Drahé kameny Českomoravské vrchoviny. Muzejní a vlastivědná společnost $v$ Brně (in Czech). Západomoravské muzeum v Třebíči, Brno.

Němec, F., 1937. Mineralogie, petrografie a geologie okolí Mohelna (monografie hadce) (in Czech). Archiv Svazu pro ochranu prírody a domoviny v zemi Moravskoslezské, 1a: 50-97.

Pouchou, J.L., Pichoir, F., 1985. "PAP" $(\varphi-\rho-Z)$ procedure for improved quantitative microanalysis. In: Microbeam Analysis. San Francisco Press (ed. J.T. Armstrong): 104-106. San Francisco.

Přichystal, A., 1984. Suroviny kamenných artefaktů (in Czech). Archeologické Rozhledy, 36: 29-30.

Přichystal, A., 2000. Stone raw materials of Neolithic-Aeneolithic polished artefacts in the Czech Republic: the present state of knowledge. Krystalinikum, 26: 119-136.

Přichystal, A., 2001. Neolitické-eneolitické broušené artefakty v České republice z hlediska kamenných surovin (in Czech). Pravěk Nová Řada, 10: 41-70.

Přichystal, A., 2002. Objev neolitické těžby zelených břidlic na jižním okraji Jizerských hor (severní Čechy) (in Czech). Kvartér, 8: 12-14.
Přichystal, A., 2013. Lithic Raw Materials in Prehistoric Times of Eastern Central Europe. Masaryk University, Brno.

Přichystal, A., Šebela, L., 1992. Lithic raw materials used by the people with Corded Ware in Moravia and the adjoining part of Upper Silesia. Scripta, 22: 29-39.

Skoczylas, J., Jochemczyk, L., Foltyn, E.M., Foltyn, E., 2000. Neolithic serpentinite tools of west-central Poland and Upper Silesia. Krystalinikum, 26: 157-166.

Stevens, R.E., 1944. Composition of some chromites of the western hemisphere. American Mineralogist, 29: 1-64.

Szakmány, Gy., Füri, J., Szolgay, Z., 2001. Outlined petrographic results of the raw materials of polished stone tools of the Miháldy-collection, Laczkó Dezs Museum, Veszprém (Hungary). In: Sites and Stones: Lengyel Culture in Western Hungary and beyond. A Review of the Current Research. Lengyel'99 and IGCP-442 Conference Veszprém (ed. J. Regenye): 109-118. Directorate of the Veszprém county Museums, Veszprém.

Šebela, L., 1999. The Corded Ware culture in Moravia and in the adjacent part of Silesia (catalogue). Archeologický Ústav Akademie Věd ČR, Brno.

Šrein, V., Šreinová, B., Št’astný, M., Šída P., Prostředník, J., 2002. Neolitický těžební areál na katastru obce Jistebsko (in Czech). Archeologie ve Středních Čechách, 6: 91-99.

Trümpy, R., 1988. A possible Jurassic-Cretaceous transform system in the Alps and the Carpathians. GSA Special Paper, 218: 93-109.

Whitney, D.L., Evans, B.W., 2010. Abbreviations for names of rock-forming minerals. American Mineralogist, 95: 185-187.

Williams-Thorpe, O., Jones, M.C., Webb, P.C., Rigby, I.J., 2000. Magnetic susceptibility thickness corrections for small artefacts and comments on the effects of "background" materials. Archaeometry, 42: 101-108.

Wojciechowski, W., 1983. Neolithic mining of lower Silesian serpentinite in the light of the excavations on Jańska Góra (in Polish with English summary). Przegląd Archeologiczny, 31:5-46.

Wojciechowski, W., 1988. Versuch der Ortsbestimmung der Produktionszentren der Äxte vom Ślę a-Typ im Lichte der petrographischen Untersuchen (in Polish with German summary). Przegląd Archeologiczny, 35: 101-138.

Wojtulek, P.M., Puziewicz, J., Ntaflos, T., Bukała, M., 2016. Podiform chromitites from the Variscan ophiolite serpentinites of Lower Silesia (SW Poland) - petrologic and tectonic setting implications. Geological Quarterly, 60 (1): 56-66.

Mapy.cz [online]. (OSeznam.cz, a.s., ONASA Earth Observatory, ( ) OpenStreetMap [cit. 2017-01-26]. Available from: https://mapy.cz/letecka? $=15.4665538 \& y=50.5693048 \& z=7$ 